\title{
Reexamination of the Late Pliocene Climate over China Using a 25-km Resolution General Circulation Model $^{\mathscr{A}}$
}

\author{
QING YAN \\ Nansen-Zhu International Research Centre, Institute of Atmospheric Physics, and Center for Excellence in \\ Tibetan Plateau Earth Sciences, Chinese Academy of Sciences, Beijing, China \\ TING WEI \\ State Key Laboratory of Severe Weather, Chinese Academy of Meteorological Sciences, Beijing, China

\section{ZHONGSHI ZHANG} \\ Department of Atmospheric Science, School of Environmental Studies, China University of Geosciences, \\ Wuhan, China, and Uni Research Climate, Bjerknes Center for Climate Research, Bergen, Norway
}

(Manuscript received 18 June 2018, in final form 25 November 2018)

\begin{abstract}
Simulations of past warm climate provide an opportunity to better understand how the climate system may respond to increased greenhouse gas emissions. Using the $\sim 25-\mathrm{km}$-resolution Community Atmosphere Model, version 4 (CAM4), we examine climate change over China in the Late Pliocene warm period (3.264-3.025 Ma) and further explore the influences of different sea surface temperature (SST) forcings and model horizontal resolutions. Initial evaluation shows that the high-resolution CAM4 performs well in capturing the climatological distribution of present-day temperature, precipitation, and low-level monsoon circulations over China. Based on the standard Pliocene Research, Interpretation and Synoptic Mapping (version 4; PRISM4) boundary conditions, CAM 4 predicts an increase of annual mean temperature by $\sim 0.5^{\circ} \mathrm{C}$ over China in the Late Pliocene relative to the preindustrial era, with the greatest warming in northwest China but cooling in southwest China. Enhanced annual mean precipitation is observed in the Late Pliocene over most of China except for northwest China where precipitation is decreased. The East Asian summer (winter) monsoon is intensified (weakened) in the Late Pliocene as suggested by geological evidence, which is attributed to the enhanced (reduced) land-sea thermal contrast. The East Asian monsoon domain exhibits a northwestward expansion in the Late Pliocene, especially over the Tibetan Plateau. Additionally, our results indicate that the modeled climate change is sensitive to the Late Pliocene SST forcings and model resolution. Particularly, different SST forcings [PRISM4-based vs Pliocene Model Intercomparison Project (PlioMIP)-based SSTs] affect the modeled phase change of summer monsoon and the associated precipitation change, while model resolution ( $25 \mathrm{vs} 400 \mathrm{~km})$ mainly impacts precipitation change.
\end{abstract}

\section{Introduction}

Climate change plays an important role in the socioeconomic development of China given its large population, limited agriculture land, and vulnerability of water resources. Thus, questions on how climate over China may respond to increased greenhouse gas concentrations

Supplemental information related to this paper is available at the Journals Online website: https://doi.org/10.1175/JCLID-18-0378.s1.

Corresponding author: Qing Yan, yanqing@mail.iap.ac.cn have been extensively investigated (Christensen et al. 2013). Although the mean temperature over China is projected to be higher in the twenty-first century, climate models vary considerably in predicting precipitation and precipitation-related extreme events, especially over subregions of China (e.g., Chen and Sun 2013; Chen et al. 2014; Zhou et al. 2014; Tian et al. 2015). Additionally, the East Asian summer monsoon will get either stronger or weaker in response to future warming according to the IPCC AR5 report (Christensen et al. 2013). These uncertainties hamper climate change hazard mitigation and adaptation policies. Hence there is growing interest in examining climate change back in time to 
better understand how the climate system may vary in a warmer-than-present world (e.g., Haywood et al. 2016a, Nie et al. 2017, 2018).

The Late Pliocene warm period [3.264-3.025 million years ago (Ma); also termed the mid-Piacenzian) attracts great interest from both numerical modeling and data synthesis given many shared similarities with projected warmer climate (Dowsett et al. 1992, 2012, 2013; Haywood et al. 2000, 2013; Salzmann et al. 2008, 2013; Naish et al. 2009; Lunt et al. 2010; Dolan et al. 2015; Hill et al. 2014; Yan et al. 2016a; Ji et al. 2017). It is characterized by elevated $\mathrm{CO}_{2}$ concentration, retreated polar ice sheets, and northward expansion of boreal forests (Haywood et al. 2016a, and references therein), which may be expected in a warmer future (Christensen et al. 2013). Global annual mean temperature in the Late Pliocene is estimated to be $\sim 1.8^{\circ}-3.6^{\circ} \mathrm{C}$ higher than the preindustrial level (Haywood et al. 2013), which is similar to the warming magnitude projected at the end of the twenty-first century, although the external forcings and time scale considered are different. Therefore, investigation of Late Pliocene climate is potentially helpful to improve our understanding of future climatic change, especially in an equilibrium state.

Numerical modeling studies have been performed to examine climate change over East Asia and specifically China since the release of the Pliocene Research, Interpretation and Synoptic Mapping (PRISM) dataset (Dowsett et al. 1994, 1999, 2010). Using the PRISM2 boundary conditions, Jiang et al. (2005) showed that mean climate over East Asia was broadly warmer and drier in the Late Pliocene, with weakened boreal summer and winter monsoon. A recent study based on the PRISM3 dataset indicated that East Asian summer monsoon was significantly strengthened in the Late Pliocene (Yan et al. 2012a), which is confirmed by the results from the Pliocene Model Intercomparison Project (PlioMIP) (Zhang et al. 2013). Based on the IPSLCM5A model results, Sun et al. (2016) suggested that enhanced mean precipitation over East Asia is largely attributed to the thermodynamic effect of warming in the Late Pliocene.

Notably, China is characterized by highly diverse topography, with the Tibetan Plateau and various mountain chains in the west and north and lower lands in the east. Previous studies have shown that the modeled temperature and precipitation over China are more realistic with finer horizontal resolution ( $\mathrm{Yu}$ et al. 2010, 2015; Gao et al. 2008, 2011; Li et al. 2015), and model resolution of $60 \mathrm{~km}$ or higher is needed to accurately reproduce precipitation distribution over China (Gao et al. 2006). However, existing Late Pliocene simulations are based on climate models with relatively coarse horizontal resolution $(\sim 100-400 \mathrm{~km})$, which may reduce the reliability of modeled regional climate change over China. Therefore, it is meaningful to reexamine climate change over China in the Late Pliocene using a highresolution climate model.

Additionally, several factors deserve further investigation to advance our knowledge of Late Pliocene climate over China. The aforementioned modeling studies have examined several aspects of climate change over China in the Late Pliocene, but little attention is paid to the migration of the East Asian monsoon boundary, which has a profound effect on regional water resources. Next, there is an obvious discrepancy in Late Pliocene sea surface temperatures (SSTs) between reconstructions and simulations (Dowsett et al. 2013; Haywood et al. 2013). The PRISM4 reconstruction suggests an El Niño-like SST anomaly over the equatorial Pacific, whereas the PlioMIP models produce an uniform warming pattern; the meridional warming contrast is more obvious in the PRISM4 reconstruction than the PlioMIP models (Fig. 1). Given uncertainties surrounding the interpretation of proxy data (e.g., O'Brien et al. 2014; Zhang et al. 2014), it is interesting to study the influence of different SST distributions on climate change over China. Last, the high-resolution model generally performs well in capturing modern climate over China, but the extent to which model horizontal resolution may affect the modeled Late Pliocene climate remains unknown.

In this study, we reexamine the Late Pliocene climate over China using a high-resolution $(\sim 25 \mathrm{~km})$ atmospheric general circulation model based on the latest standard version of PRISM4 boundary conditions that use the modern continental configurations (Dowsett et al. 2016), and further explore the influences of SST forcings and model horizontal resolution. We attempt to provide a possible scenario on climate change over China with a horizontal resolution of $\sim 25 \mathrm{~km}$ during the Late Pliocene warm period. The remainder of the paper is organized as follows. The model and experimental design are described in section 2. In section 3, we evaluate the performance of the high-resolution model in simulating mean climate over China. Results on climate change in the Late Pliocene are documented in section 4. Sensitivity of climate change to the Late Pliocene SST forcings and model resolution is examined in section 5. Model-data comparisons and potential implications of our results are discussed in section 6 . We conclude this study in section 7 .

\section{Model and experimental design}

We use the Community Atmosphere Model, version 4 (CAM4), to investigate climate change over China in the Late Pliocene. CAM4 is developed at the National 

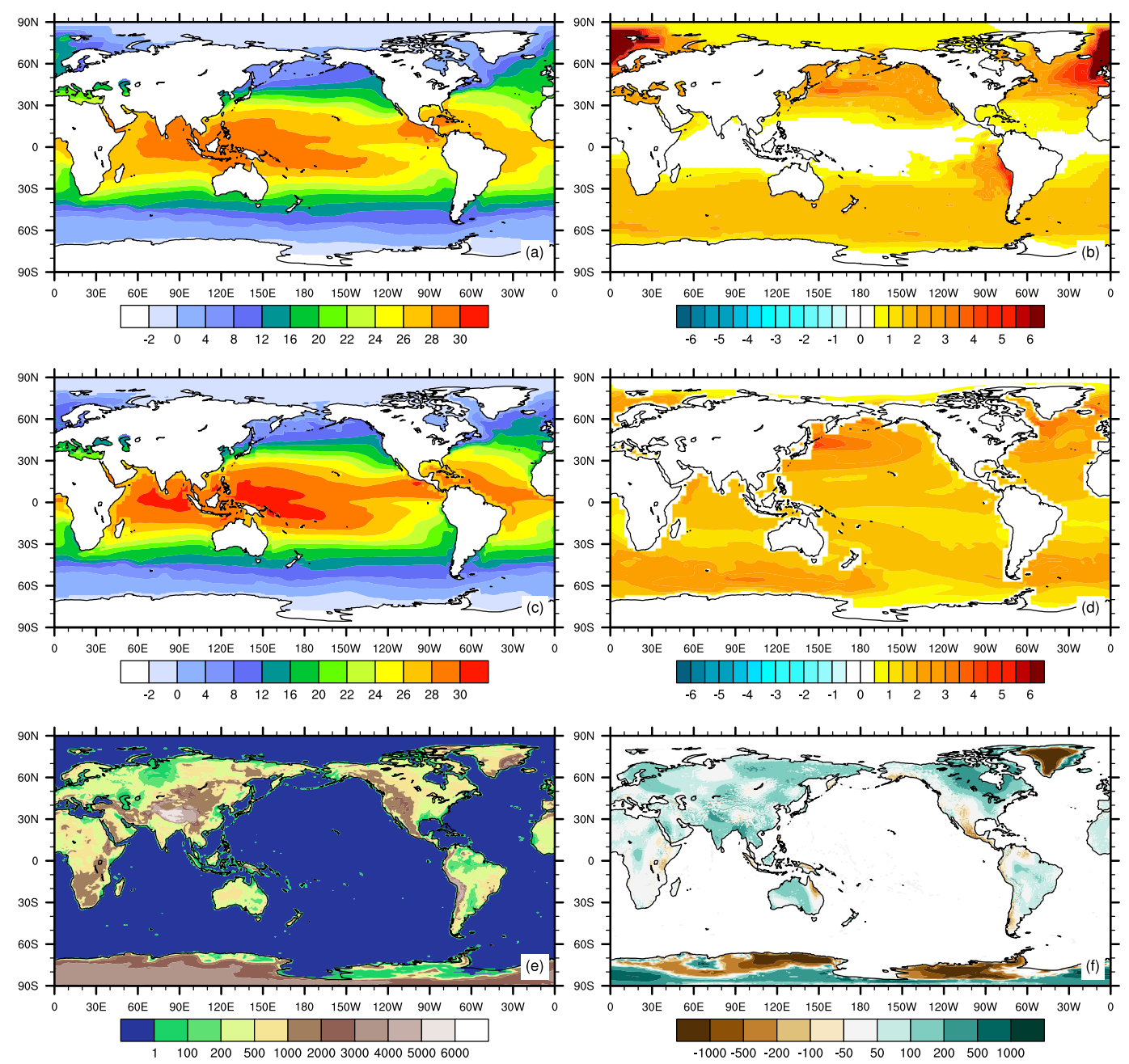

FIG. 1. (a) Late Pliocene SSTs $\left({ }^{\circ} \mathrm{C}\right)$ based on the PRISM4 dataset and (b) SST anomaly $\left({ }^{\circ} \mathrm{C}\right)$ relative to the preindustrial era. (c) Late Pliocene SSTs $\left({ }^{\circ} \mathrm{C}\right)$ based on the ensemble mean of the PlioMIP models and (d) SST anomaly $\left({ }^{\circ} \mathrm{C}\right)$ relative to the preindustrial era. (e) The Late Pliocene topography $(\mathrm{m})$ based on the PRISM4 dataset and (f) elevation anomaly $(\mathrm{m})$ relative to the preindustrial era.

Center for Atmospheric Research, and is coupled with the Community Land Model, version 4 (CLM4), with prescribed SSTs (Neale et al. 2010). In this study, CAM4 uses a finite-volume dynamical core and has a horizontal resolution of $0.23^{\circ}$ latitude $\times 0.31^{\circ}$ longitude $(\sim 25 \mathrm{~km}$ at the equator) with 26 vertical levels. Note that the values of parameters and parameterizations are set to the default values at the standard resolution (i.e., $0.9^{\circ} \times 1.25^{\circ}$ )

TABLE 1. Summary of the experimental design. PlioMIP2 suggests a $\mathrm{CO}_{2}$ concentration of $400 \mathrm{ppmv}$, but a difference of 5 ppmv may have limited effect on the modeled climate change. PRISM4 SSTs are identical to the PRISM3 SSTs.

\begin{tabular}{|c|c|c|c|c|c|}
\hline & \multicolumn{2}{|c|}{ CCAM4 $\left(3.75^{\circ} \times 3.75^{\circ}\right)$} & \multicolumn{3}{|c|}{$\operatorname{HCAM} 4\left(0.23^{\circ} \times 0.31^{\circ}\right)$} \\
\hline & Preindustrial & Late Pliocene & Preindustrial & Late Pliocene (PRISM) & Late Pliocene (PlioMIP) \\
\hline $\mathrm{CO}_{2}$ & $280 \mathrm{ppmv}$ & $405 \mathrm{ppmv}$ & $280 \mathrm{ppmv}$ & 405 ppmv & 405 ppmv \\
\hline SSTs & Modern & PRISM3 & Modern & PRISM4 & PlioMIP \\
\hline Topography & Modern & PRISM3 & Modern & PRISM4 & PRISM4 \\
\hline Land cover & Modern & PRISM3 & Modern & PRISM3 & PRISM3 \\
\hline Lakes and soils & Modern & Modern & Modern & PRISM4 & PRISM4 \\
\hline Land-sea mask & Modern & Modern & Modern & Modern & Modern \\
\hline
\end{tabular}


without additional tuning to facilitate the comparisons with low-resolution model results.

According to the PlioMIP guidelines (Haywood et al. 2010, 2011, 2016b), we first carry out a preindustrial experiment and a Late Pliocene experiment using the high-resolution CAM4 (referred to as HCAM4). In the preindustrial experiment, we set $\mathrm{CO}_{2}$ concentration to 280 ppmv and use the default high-resolution boundary conditions in CESM. In brief, the modern topography is constructed by converting the Global 30-Arc-Second Elevation dataset to the resolution of $0.23^{\circ} \times 0.31^{\circ}$, and the SST fields are derived from the monthly mean Hadley Centre Sea Ice and Sea Surface Temperature dataset (HadISST) version 1 and from version 2 of the National Oceanic and Atmospheric Administration dataset (Hurrell et al. 2008) via bilinear interpolation. The land cover datasets are remapped from a set of "raw" data files (e.g., modern vegetation types and leaf/ stem areas), most of which are at $0.5^{\circ}$ resolution. In the Late Pliocene experiment, $\mathrm{CO}_{2}$ concentration increases to 405 ppmv, with monthly mean SSTs, topography, and land cover changed to the conditions of the Late Pliocene based on the PRISM4 dataset (Table 1 and Fig. 1). In the Late Pliocene, extensive oceanic warming is observed at high latitudes in the North Atlantic, whereas low-latitude SSTs, except for upwelling regions, are similar to modern conditions (Fig. 1b; Dowsett et al. 2009). Moreover, North Pacific and South Ocean experience an increase of temperature by $\sim 1^{\circ}-4^{\circ} \mathrm{C}$ in the Late Pliocene. The topographies of Greenland, West Antarctica, and parts of East Antarctica are $>1000 \mathrm{~m}$ lower in the Late Pliocene relative to those of the present day owing to the decrease in the size of the polar ice sheets (Fig. 1f). Lower topographies are also found over the Rocky Mountains and Andes Plateau. However, topographies of the other regions are generally higher in the Late Pliocene relative to the present. Regarding to the spatial distribution of vegetation, boreal forests extend northward at the northern high latitudes in the Late Pliocene and desert areas are reduced (Salzmann et al. 2008); tundra appears in Greenland and Antarctica because of the reduced size of the ice sheets. Additionally, we perform a sensitivity experiment to investigate the influence of SST forcings, in which Late Pliocene SST anomalies are derived from ensemble mean of the PlioMIP models (Haywood et al. 2013).

Specifically, we create the Late Pliocene SST and topography fields using the "anomaly" method as suggested by the PlioMIP (Haywood et al. 2010). We first interpolate the SST and topography anomalies derived from the PRISM4 dataset $\left(2^{\circ} \times 2^{\circ}\right)$ to the CAM4 model resolution $\left(0.23^{\circ} \times 0.31^{\circ}\right)$ using bilinear interpolation,
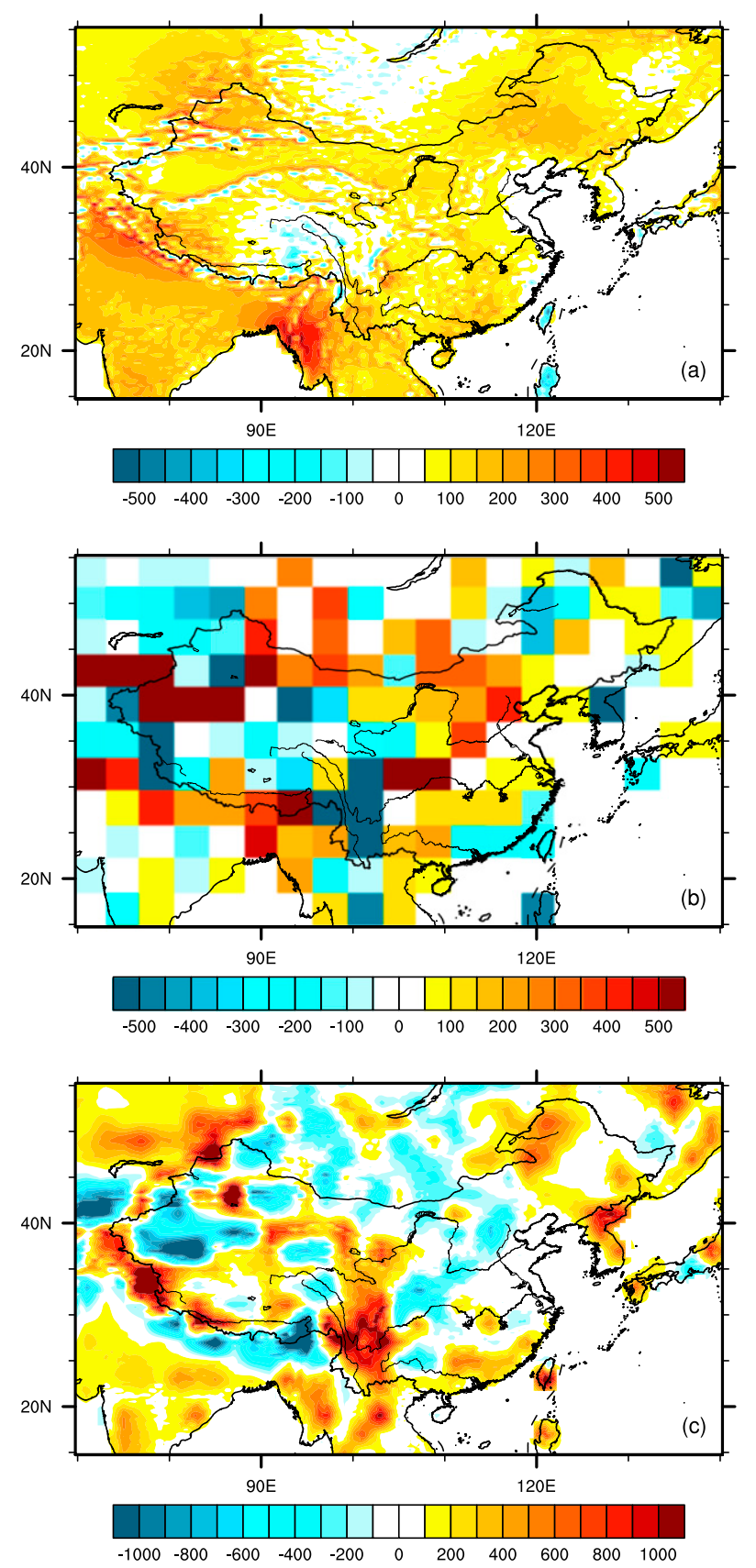

FIG. 2. Topography anomaly $(\mathrm{m})$ between the Late Pliocene and present based on (a) the PRISM4 dataset used in the HCAM4 and (b) the PRISM3 dataset used in the CCAM4. (c) Differences in topography $(\mathrm{m})$ between $(\mathrm{a})$ and $(\mathrm{b})$.

and then add these anomalies to the climatology used in the preindustrial experiment. For the land cover, the reconstructed Late Pliocene land cover is first converted to Land Surface Model land cover types and then to the plant functional types used in CLM. The created land cover datasets $\left(2^{\circ} \times 2^{\circ}\right)$ are then converted to the high resolution of CAM4 using the tools in CESM/CLM4 

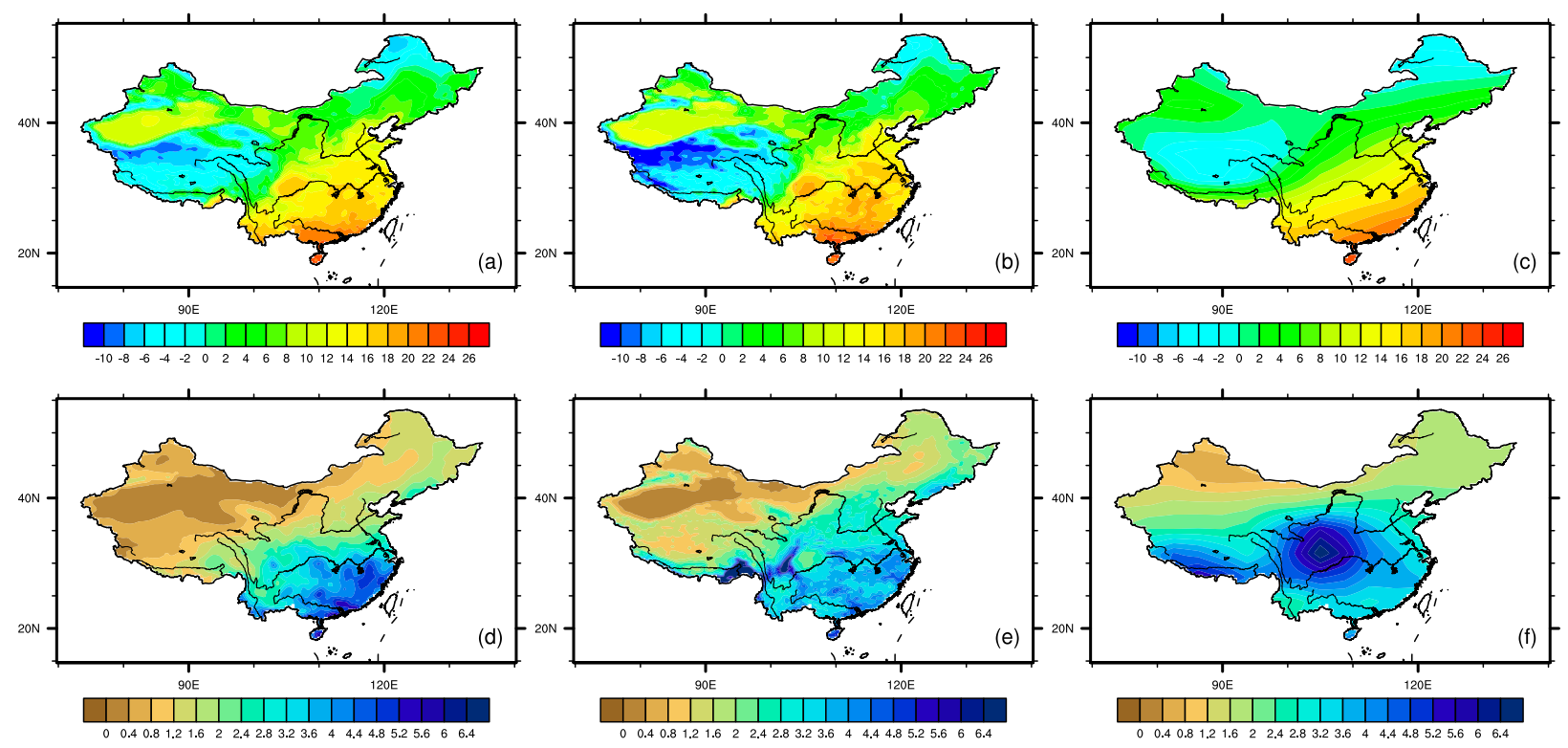

FIG. 3. Spatial distribution of (a)-(c) present-day temperature $\left({ }^{\circ} \mathrm{C}\right)$ and $(\mathrm{d})-(\mathrm{f})$ precipitation $\left(\mathrm{mm} \mathrm{day}^{-1}\right)$ over China from (a),(d) observations, (b),(e) HCAM4, and (c),(f) CCAM4.

(e.g., mksurfdata_map). Note that the potential role of Pliocene tropical seaway closure in East Asian climate is ignored here (Cane and Molnar 2001; Nie et al. 2014; Zhang et al. 2016; Karas et al. 2017). Detailed methods for constructing boundary conditions used in the CAM model can be found in Yan et al. (2012b).
Because atmospheric models generally adjust to initial perturbation within several months (Simmonds 1985) and high-resolution climate simulation requires huge computational resources, we run the preindustrial experiment for 7 years and the two Late Pliocene experiments for 10 years to let the surface climate reach
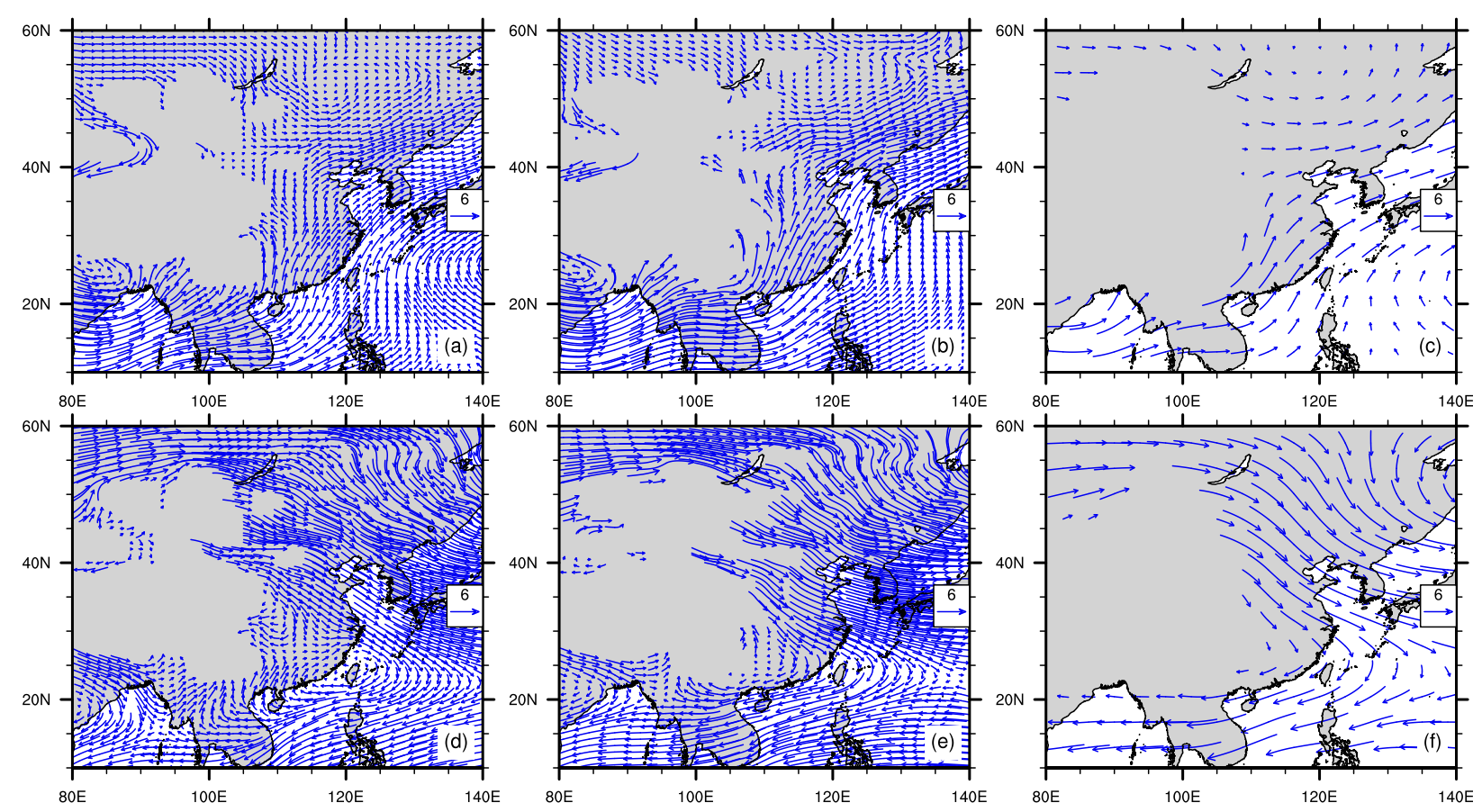

FIG. 4. Spatial distribution of present-day wind fields at $850 \mathrm{hPa}\left(\mathrm{m} \mathrm{s}^{-1}\right)$ in (a)-(c) summer and (d)-(f) winter over East Asia from (a),(d) ERA-Interim, (b),(e) HCAM4, and (c),(f) CCAM4. 
quasi-equilibrium (Yan et al. 2016b). The last 5 years of results are analyzed here. However, we acknowledge that the relatively short length of the model run may introduce uncertainty into the quantitative results reported here.

To explore climatic effect of model horizontal resolution, we perform the preindustrial and Late Pliocene experiments using a coarse-resolution CAM4 (referred to as CCAM4) but based on the PRISM3 dataset. The resolution of the CCAM4 is approximately $3.75^{\circ}$ in the horizontal and 26 levels in the vertical. For the CCAM4, the two experiments are integrated for 50 years, and the last 20 years of data are used. More information concerning the CCAM4 simulations is given in Zhang and Yan (2012).

We emphasize at the outset that the differences between the HCAM4 and the CCAM4 experiments are attributed to different horizontal resolutions and boundary conditions. The largest differences in boundary conditions between HCAM4 and CCAM4 Late Pliocene experiments are the topographies used (Table 1). With respect to China, the topographies are broadly higher over the Tibetan Plateau and various mountain chains in the PRISM4 reconstruction relative to the PRISM3, whereas they are lower over the Tarim basin and north China plains (Fig. 2). Although it is not a perfect comparison, this investigation may shed some light on the possible role of model resolution.

\section{Performance of the HCAM4 over China}

The HCAM4 can reasonably reproduce the observed spatial pattern of modern temperature and precipitation over China. Compared with the observations (Wu and Gao 2013), the HCAM4 successfully predicts relatively higher temperature in southern China and lower temperature in northeast China and the Tibetan Plateau (Figs. 3a,b). The local features of temperature distribution, especially in the Tibetan Plateau and southern China, are well captured in the HCAM4 owing to its finer resolution. The spatial correlation coefficient of temperature between the HCAM4 and observations is approximately 0.98, with a root-mean-square error of $\sim 1.8^{\circ} \mathrm{C}$. For the annual mean precipitation, the HCAM4 captures the gradually decreased precipitation from southeast to northwest China shown in observations (Figs. 3d,e). Particularly, the HCAM4 improves the simulated precipitation in the midwestern part of China (e.g., the Sichuan basin), where a large virtual precipitation center appears in the majority of climate models with coarse horizontal resolution (e.g., Fig. 3f). Meanwhile,
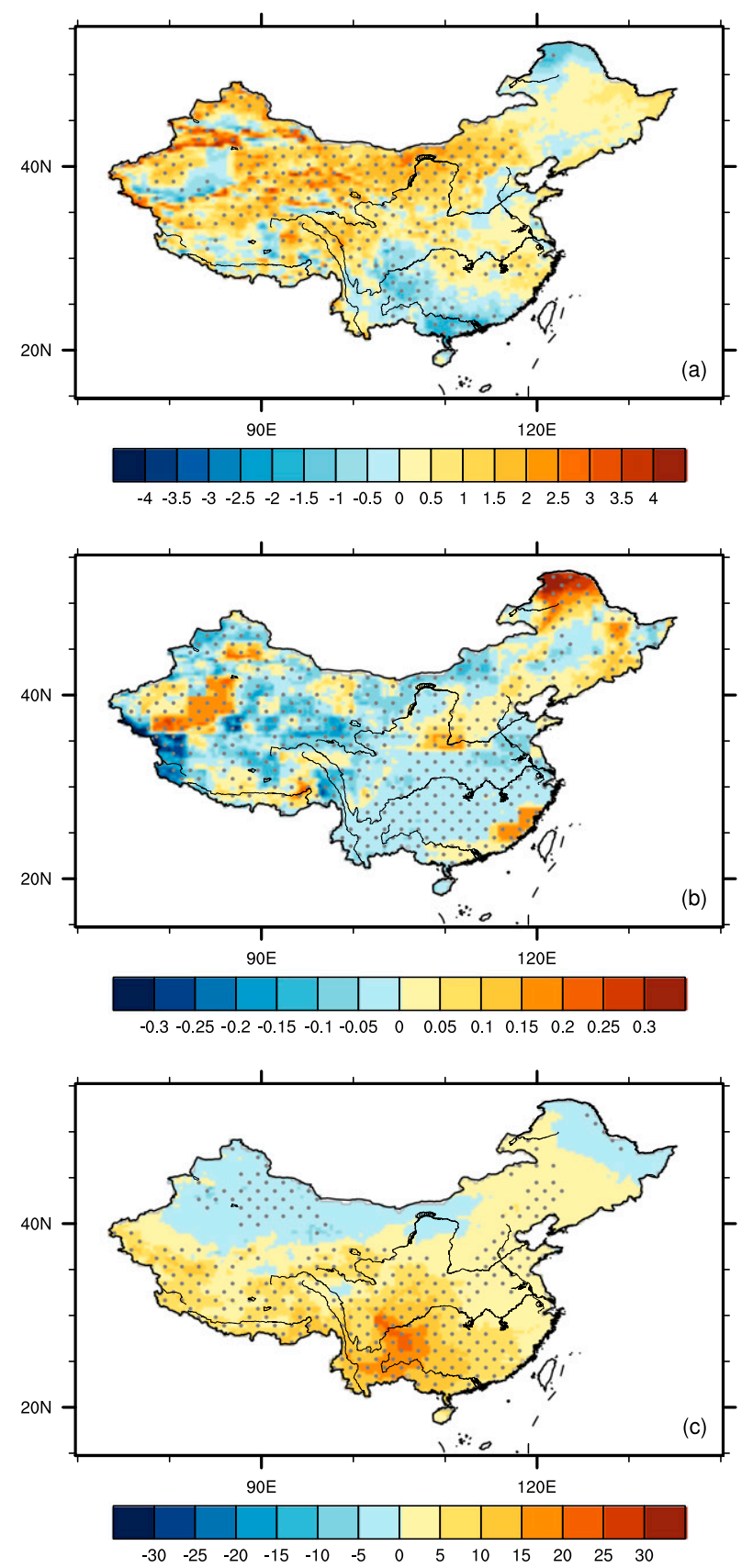

FIG. 5. Differences in (a) annual mean surface air temperature $\left({ }^{\circ} \mathrm{C}\right)$, (b) surface albedo, and (c) total cloud amount (\%) between the Late Pliocene and preindustrial. Areas that pass the $95 \%$-levelof-significance test are dotted.

the HCAM4 broadly reproduces the local precipitation characteristics in southern China, although the magnitude is underestimated. The centered spatial correlation coefficient and root-mean-square error are $\sim 0.77$ and $1.1 \mathrm{~mm} \mathrm{day}^{-1}$, respectively, between the HCAM4 and observations. However, the spatial correlations (root-mean-square error) for temperature 


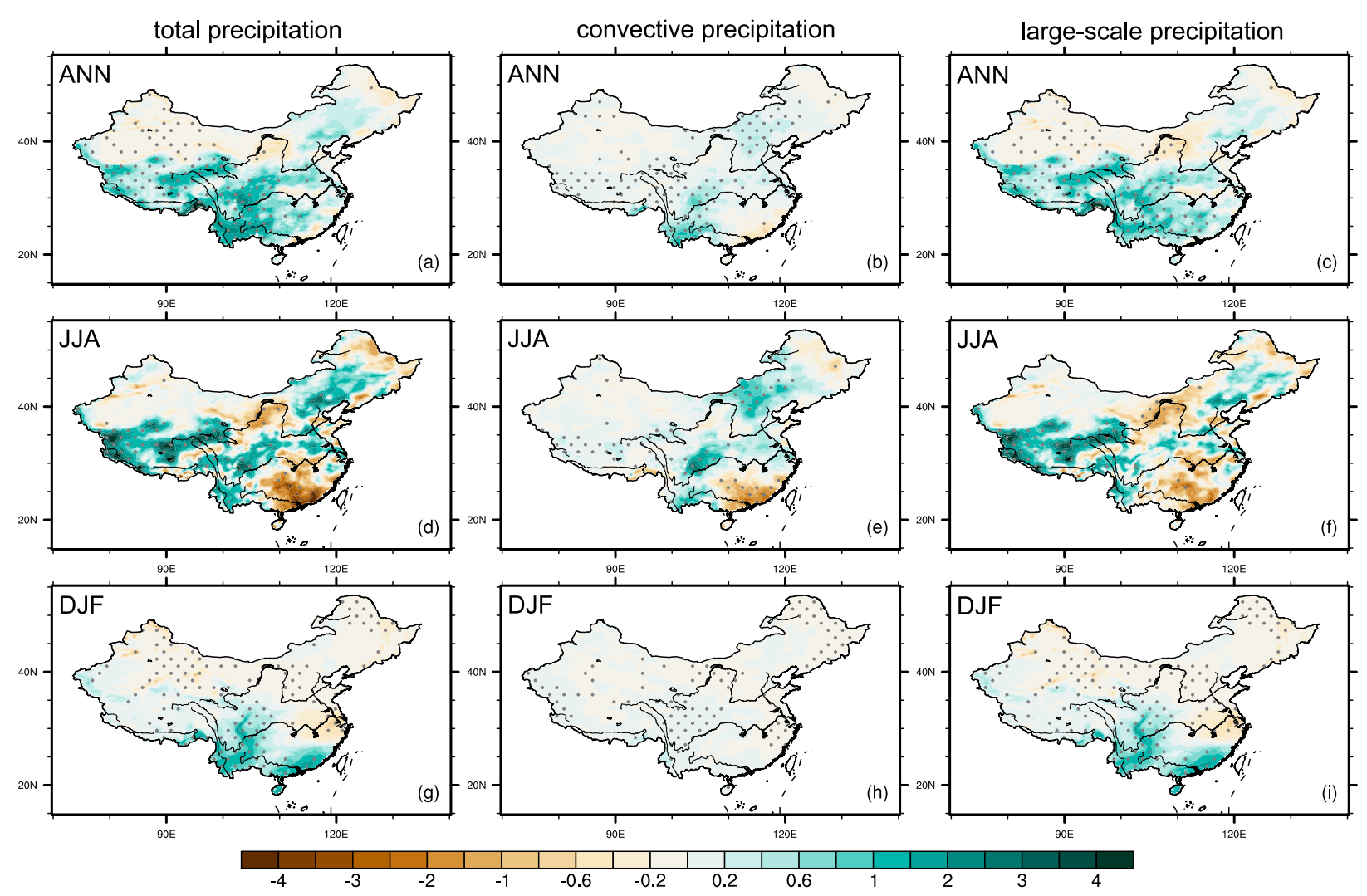

FIG. 6. Differences in (a),(d),(g) total precipitation, (b),(e),(h) convective precipitation, and (c),(f),(i) large-scale precipitation (all in $\mathrm{mm} \mathrm{day}^{-1}$ ) between the Late Pliocene and preindustrial for (a)-(c) the annual mean, (d)-(f) summer, and (g)-(i) winter. Areas that pass the $90 \%$-level-of-significance test are dotted.

and precipitation in the CCAM4 are $0.85\left(4.1^{\circ} \mathrm{C}\right)$ and $0.56\left(1.7 \mathrm{~mm} \mathrm{day}^{-1}\right)$, respectively. Therefore, the HCAM4 performs much better in simulating presentday temperature and precipitation over China, which is largely attributed to the resolved details of topography that enable more explicitly resolved physical and dynamical processes in HCAM4 than in CCAM4 (e.g., Li et al. 2015).

The large-scale characteristics of low-level wind fields (at $850 \mathrm{hPa}$ ) are also well captured in the HCAM4. The HCAM4 reproduces the southwesterly over southern China in summer and the northwesterly over northern China in winter as revealed by the reanalysis data (Dee et al. 2011) (Fig. 4). The HCAM4 provides more information on local features of low-level wind fields (e.g., over the Hexi Corridor) that cannot be resolved in a coarse-resolution model (Figs. 4c,f). It is noted that spatial pattern of summer and winter winds over eastern China is broadly similar between the HCAM4 and CCAM4 (Fig. 4). Overall, the HCAM4 exhibits high skill in depicting modern climate over China, which potentially improves our confidence in using it to explore past climate change.

\section{Climate change in the Late Pliocene}

\section{a. Temperature and precipitation}

The HCAM4 broadly predicts a warmer climate with higher precipitation over China in the Late Pliocene relative to the preindustrial. The regionally averaged annual mean temperature increases by $\sim 0.5^{\circ} \mathrm{C}$ over China in the Late Pliocene, which is smaller than the warming magnitude averaged across the globe $\left(\sim 1.9^{\circ} \mathrm{C}\right)$. For the spatial pattern, higher temperature is observed over the majority of China in the Late Pliocene, especially over northwest China (Fig. 5a). Decreased temperature $\left(0.5^{\circ}-2^{\circ} \mathrm{C}\right)$ is mainly located over southwest China. The cooling may result from increased total cloud amount in the Late Pliocene that is associated with enhanced convection activity there (Figs. 5b,c), with positive contributions from higher topography $\left(\sim 0.33^{\circ}-\right.$ $0.65^{\circ} \mathrm{C}$ using a lapse rate of $6.5^{\circ} \mathrm{C} \mathrm{km}^{-1}$ ).

Annual mean precipitation increases by $\sim 0.4 \mathrm{~mm}$ day $^{-1}$ over China in the Late Pliocene, with an increase of precipitation by $\sim 0.1$ and $0.3 \mathrm{~mm} \mathrm{day}^{-1}$ in summer and winter, respectively. Enhanced annual mean precipitation mainly appears in the Tibetan Plateau and southwest 

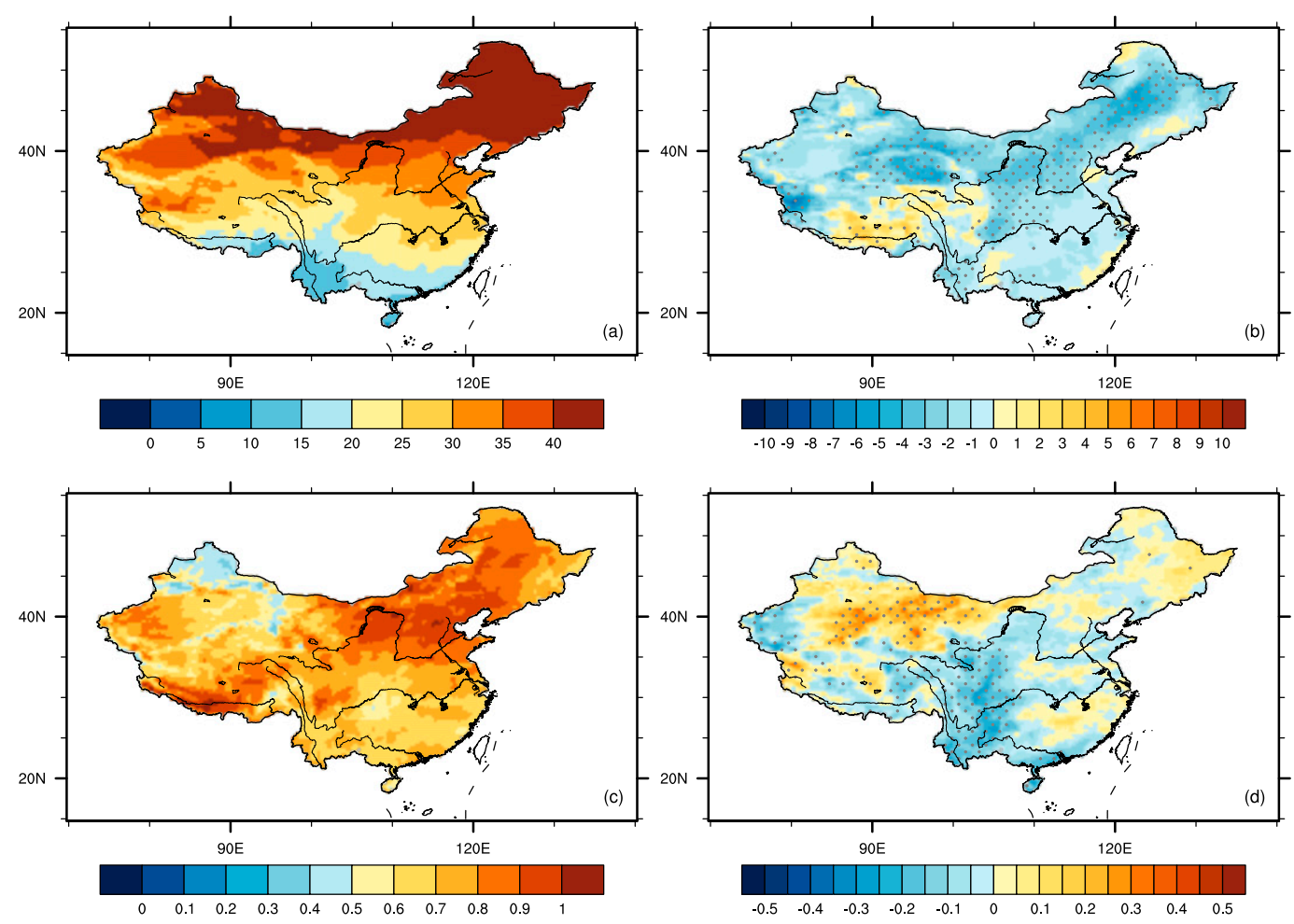

FIG. 7. Modeled (a),(b) temperature $\left({ }^{\circ} \mathrm{C}\right)$ and (c),(d) precipitation seasonality in (a),(c) the preindustrial and (b), (d) its change in the Late Pliocene (Late Pliocene minus preindustrial). Areas that pass the $90 \%$-level-of-significance test are dotted.

China, which is largely attributed to the increase in large-scale precipitation (Figs. 6a-c). Significantly decreased precipitation is found over northwest China in the Late Pliocene. The spatial pattern of precipitation anomalies varies for different seasons. In summer, precipitation decreases in the southern portion of the Yangtze River and in the middle reaches of the Yellow River valley, while it shows an increase between them (Fig. 6d). Increased precipitation is also seen in the Tibetan Plateau and parts of northeast China. These precipitation anomalies mainly result from changes in large-scale precipitation, but convective precipitation plays a certain role over the southeast and midwestern parts of China (Figs. 6e,f). Regarding winter precipitation, the most intense changes occur in southern China where precipitation increases significantly by $\sim 0.5-2.0 \mathrm{~mm} \mathrm{day}^{-1}$ in the Late Pliocene (Fig. $6 \mathrm{~g}$ ). The enhanced precipitation is dominated by the increase in large-scale precipitation (Figs. 6h,i).

Moreover, we examine seasonality changes in precipitation and temperature in the Late Pliocene (Fig. 7), which may shed light on the interpretation of paleoclimate proxies. Temperature seasonality, defined as the difference between the annual maximum and minimum temperatures, is broadly decreased over the majority of
China in the Late Pliocene relative to the preindustrial era (Fig. 7b). This results from larger warming in winter than in summer. For the precipitation seasonality, it is defined as $\mathrm{SI}=\left(\sum_{n=1}^{12}\left|X_{n}-R / 12\right|\right) / R$, where $R$ is the annual total precipitation and $X_{n}$ is the monthly precipitation for month $n$ (Walsh and Lawler 1981). It is shown in Fig. 7d that precipitation seasonality is significantly reduced over southwestern and central China in the Late Pliocene, partly arising from greatly increased precipitation in winter (Fig. 6g), whereas reduced precipitation seasonality over the Yellow River basin (i.e., the Loess Plateau) and parts of southern China results from decreased precipitation in summer (Fig. 6d). In contrast, precipitation seasonality becomes more profound over northwestern and far northeastern China in the Late Pliocene, which is mainly attributed to decreased winter precipitation.

\section{b. Monsoonal circulations}

There is an obvious southwesterly anomaly at $850 \mathrm{hPa}$ over southern China in summer in the Late Pliocene (Fig. 8a), indicating an enhanced East Asian summer monsoon as suggested by multiproxies (e.g., Nie et al. 2007, 2014). At the middle level of the troposphere $(500 \mathrm{hPa})$, geopotential height is higher over the western 


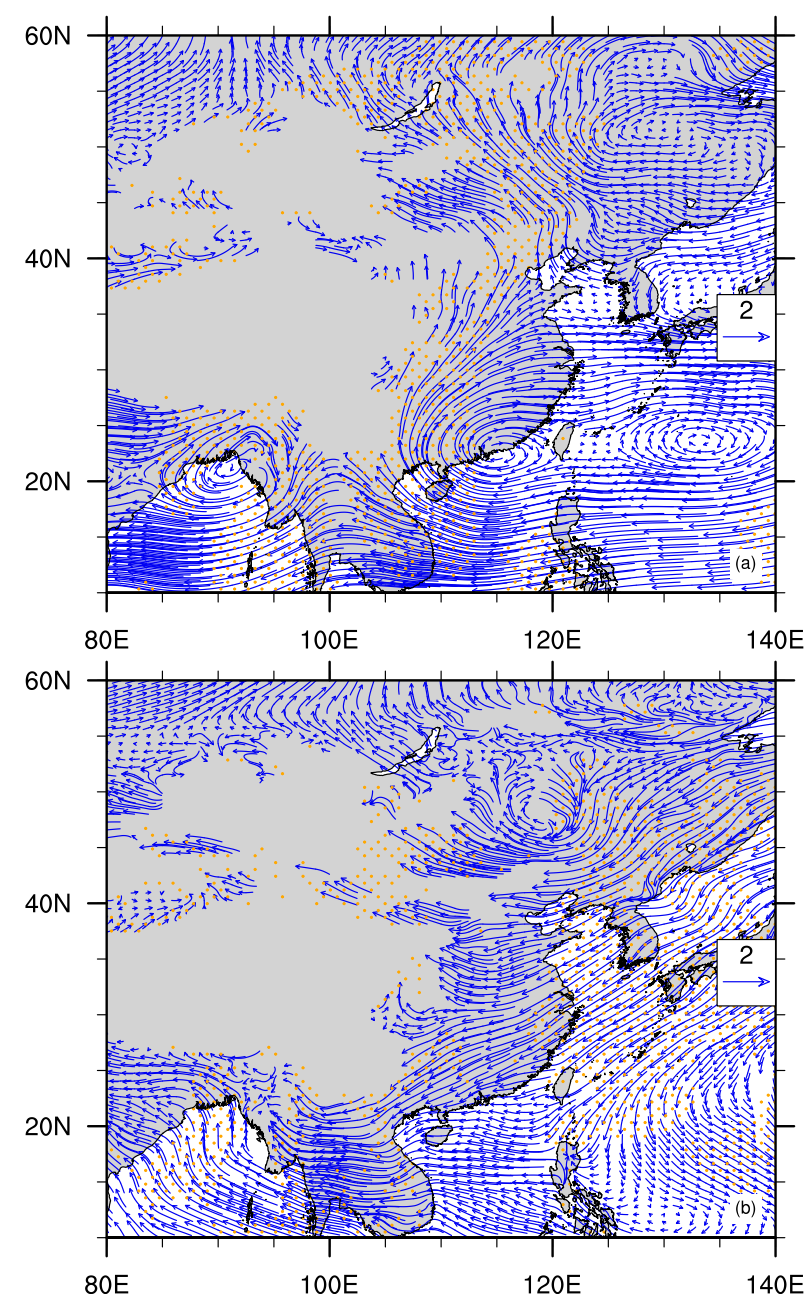

FIG. 8. Differences in 850-hPa wind fields $\left(\mathrm{m} \mathrm{s}^{-1}\right)$ in (a) summer and (b) winter between the Late Pliocene and preindustrial. Areas where meridional wind passes the $95 \%$-level-of-significance test are dotted.

North Pacific in the Late Pliocene and geopotential isolines migrate westward compared with the presentday position (Fig. 9a). This result suggests a westward shift of the western North Pacific subtropical high (WNPSH) in the Late Pliocene, which may be partially attributed to the El Niño-like SST pattern in the Late Pliocene that leads to weaker atmospheric convection over the warm pool (e.g., Lu and Dong 2001). The westward shift of the WNPSH leads to an anticyclone anomaly over southern China (i.e., high pressure anomaly; Fig. 8a), resulting in deficient precipitation over that region. At the upper level $(200 \mathrm{hPa})$, the East Asian westerly jet (EAWJ), which is centered along $\sim 40^{\circ} \mathrm{N}$ and is closely related to summer precipitation over China (Ding and Chan 2005), roughly exhibits a meridional dipole pattern in summer in the Late Pliocene relative to the preindustrial
(Fig. 9c). The zonal wind is decreased to the south of $\sim 45^{\circ} \mathrm{N}$ and is enhanced to the north. This result indicates a poleward migration of the EAWJ, which generally corresponds to a northward shift of the monsoon rain belt and less precipitation over southern China (Zhou and $\mathrm{Yu}$ 2005). Meantime, the intensity of the EAWJ is weakened because of the reduced meridional temperature gradient in the Late Pliocene (Fig. 9e), which is unfavorable for precipitation over the middle reaches of the Yellow River by preventing water vapor transport from upstream regions.

During the winter season, a southeasterly anomaly is observed over northern China in the Late Pliocene relative to the preindustrial (Fig. 8b), suggesting a weakened East Asian winter monsoon in the Late Pliocene supported by the reconstructions (e.g., Nie et al. 2014). The geopotential height at $500 \mathrm{hPa}$ is increased over the mid- to high latitudes of East Asia (Fig. 9b). This result indicates a weakened East Asian trough in the Late Pliocene, which is generally associated with a southeasterly anomaly over northern China ( $\mathrm{He}$ and Wang 2012). Zonal wind at $200 \mathrm{hPa}$ is enhanced at low latitudes of East Asia and is decreased at mid- to high latitudes in the Late Pliocene (Fig. 9d). This result suggests a weaker and southward shift of the EAWJ, which contributes positively to the enhanced precipitation over southern China (Yang et al. 2002).

The spatial structure of East Asian monsoon variation can be deciphered in terms of the effects of land-sea thermal contrast (Wang 2006). Here we use the tropospheric mean temperature $(200-500 \mathrm{hPa})$ to measure the thermal condition according to previous studies (e.g., Zhou and Zou 2010; Man et al. 2012). In summer warm temperature anomalies dominate over East Asia in the Late Pliocene, whereas cool anomalies are observed in the tropical western Pacific (Fig. 9e). As the climatological mean tropospheric temperature is characterized by a "warm land-cold ocean" condition in summer, this result suggests an enhanced land-sea thermal contrast and hence increased sea level pressure gradient, which favors a stronger summer monsoon circulation. Tropospheric mean temperature anomalies exhibit a similar pattern in winter, with increased temperature over East Asia and slight cooling in the tropical western Pacific (Fig. 9f). Wintertime tropospheric mean temperature generally shows a "cold land-warm ocean" condition, so the land-sea thermal contrast and sea level pressure gradient is reduced in the Late Pliocene, indicating a weaker winter monsoon circulation.

\section{c. East Asian monsoon domain}

The East Asian monsoon domain is defined as the region in which the local summer minus winter precipitation (i.e., the annual range) exceeds $2 \mathrm{~mm}_{\text {day }}{ }^{-1}$ 

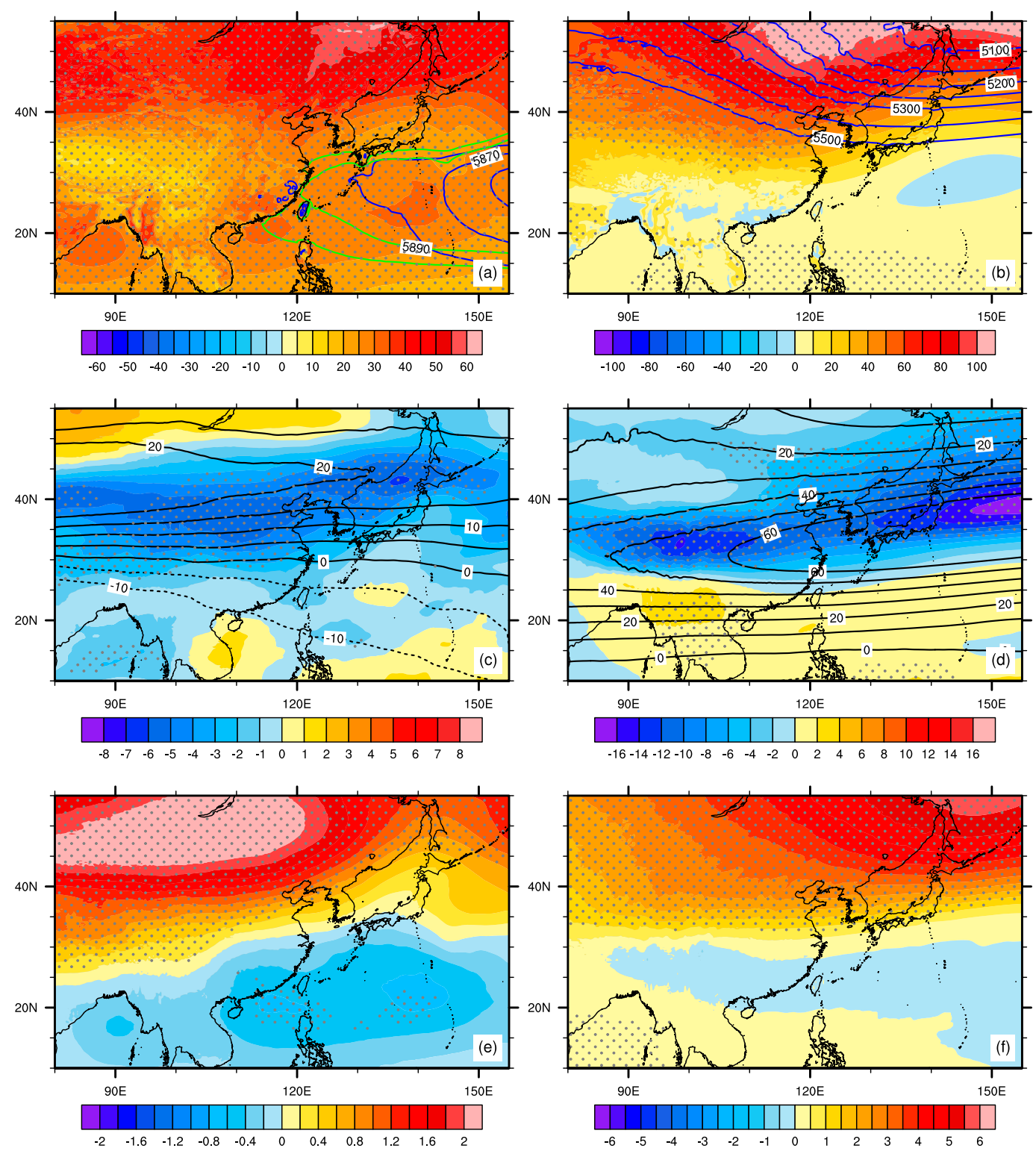

FIG. 9. (top) Differences in 500-hPa geopotential height (gpm) in (a) summer and (b) winter between the Late Pliocene and preindustrial. The explicit geopotential isolines in the preindustrial and Late Pliocene are shown by solid blue and green lines, respectively. (middle) Differences in 200-hPa zonal wind $\left(\mathrm{m} \mathrm{s}^{-1}\right)$ in (c) summer and (d) winter between the Late Pliocene and preindustrial. The $200-\mathrm{hPa}$ zonal wind in the preindustrial experiment is shown by contours. (bottom) Differences in mean upper-tropospheric $(500-200 \mathrm{hPa})$ temperature $\left({ }^{\circ} \mathrm{C}\right)$ in (e) summer and (f) winter between the Late Pliocene and preindustrial. Areas that pass the 95\%-level-of-significance test are dotted.

and the local summer precipitation exceeds $55 \%$ of annual total precipitation (Wang and Ding 2006; Wang et al. 2012). Although this metric is initially proposed to depict global monsoon domain, it has been proven to be skillful in measuring East Asian monsoon domain and has been widely used in both past and future climates (e.g., Wang et al. 2014; Tian and Jiang 2015). Because of the improvement in the simulated precipitation, the HCAM4 overcomes the bias found in coarse resolution of the state-of-the-art climate models such that parts of eastern China (e.g., the lower reaches of the Yangtze River valley) do not belong to East Asian monsoon domain in the present (e.g., Lee and Wang 2014) (Fig. 10a). It is shown that the East Asian monsoon domain generally expends northwestward in the Late Pliocene, especially in the Tibetan Plateau (Fig. 10b), 

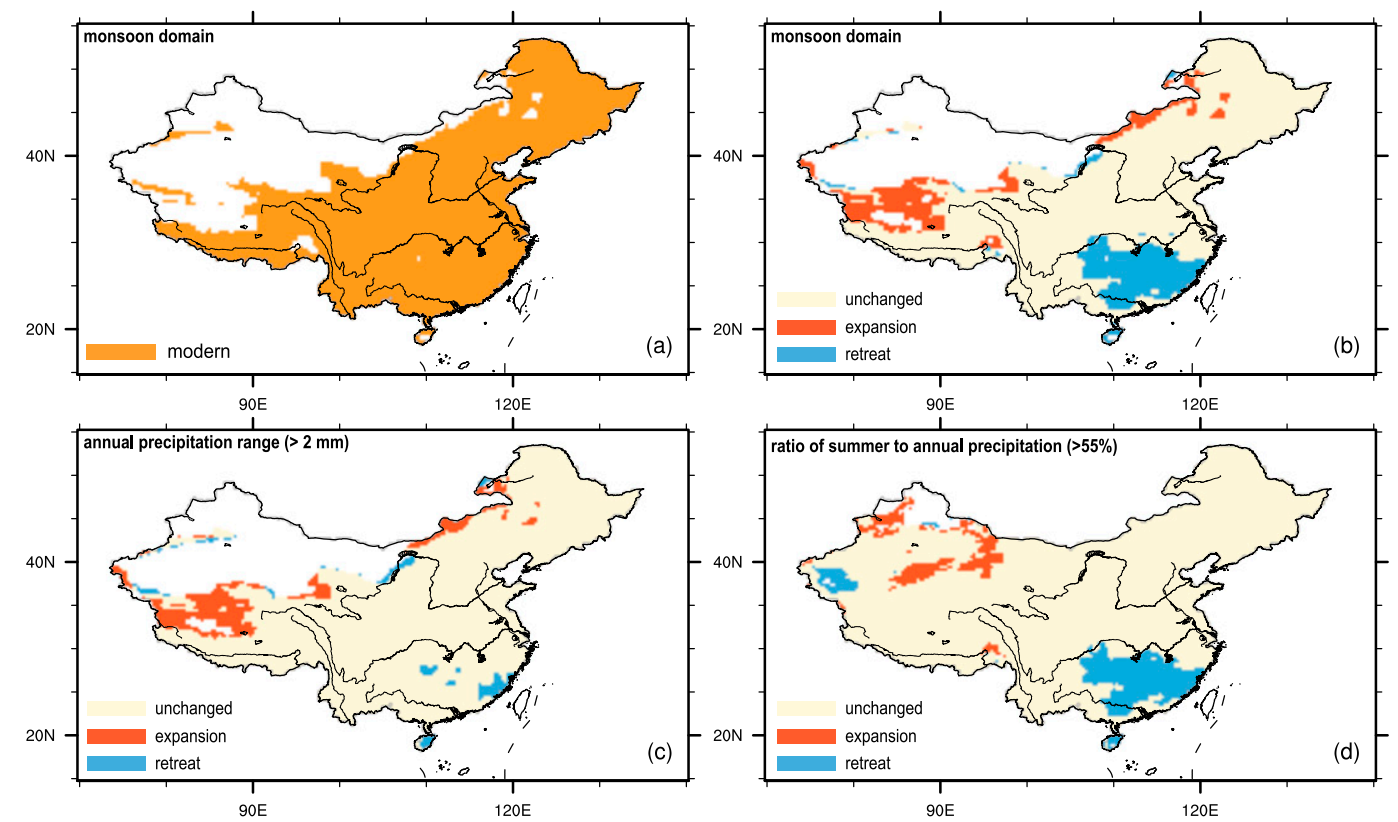

FIG. 10. The simulated East Asian monsoon domain in (a) the preindustrial and (b) its change in the Late Pliocene (Late Pliocene minus preindustrial), and differences in the domain (c) with annual precipitation range $>2 \mathrm{~mm}$ and (d) with ratio of summer to annual precipitation $\geq 55 \%$ between the Late Pliocene and preindustrial.

which is caused by the increased summer precipitation and hence larger annual range (Fig. 10c). This phenomenon is similar to the conditions from the Last Glacial Maximum to the mid-Holocene (Yang et al. 2015) and in the twenty-first century (Lee and Wang 2014). In contrast, the monsoon domain retreats over the middle reaches of the Yellow River and southern China in our simulations, resulting from decreased summer precipitation and reduced precipitation seasonality (Figs. 10c,d), respectively.

\section{Sensitivity to Late Pliocene SST forcing and model horizontal resolution}

\section{a. Late Pliocene SST forcing}

To investigate the role of different SST forcings in climate change over China, we carry out a sensitivity Late Pliocene experiment in which SST anomalies are derived from the ensemble mean of the PlioMIP models. Driven by the PlioMIP model-based SSTs, the HCAM4 shows an increase of annual mean temperature by $\sim 0.7^{\circ} \mathrm{C}$ over China compared to the preindustrial. Higher temperatures are found almost over all of China except for the northeast (Fig. 11a). Anomalies in summer precipitation exhibit a tripole pattern over east China in the Late Pliocene, with enhanced precipitation over the Yangtze River and reduced precipitation along its two sides. Increased precipitation is also observed over central China and the Tibetan Plateau (Fig. 11c). During the winter season, precipitation is increased south of $35^{\circ} \mathrm{N}$ in the Late Pliocene, whereas it is broadly decreased to the north (Fig. 11e). Additionally, the East Asian monsoon domain shows a northwestward migration in the Late Pliocene, whereas it retreats over parts of southeast China (Fig. 11g). For the monsoonal circulations, both the East Asian summer monsoon and winter monsoon are weakened in the Late Pliocene due to reduced land-sea thermal contrast (Figs. 12a,d).

We find that the two Late Pliocene simulations give similar results in terms of the warming magnitude over China as well as variations of East Asian monsoon domain. The largest discrepancy appears to be changes in monsoonal circulation and associated precipitation variations. Forced by the PRISM4-based SSTs, the HCAM4 predicts a stronger East Asian summer monsoon (Fig. 8a), whereas the summer monsoon is weakened in response to the PlioMIP model-based SSTs (Fig. 12a). This discrepancy is largely attributed to the temperature difference over the tropical Pacific warm pool between the two SST fields: SSTs are $1^{\circ}-2^{\circ} \mathrm{C}$ higher in the PlioMIP simulations relative to the preindustrial, whereas they exhibit a slighter change or even cooling in the PRISM4 reconstructions (Fig. 1). This SST difference leads to a relatively "warmer ocean-colder land" pattern in terms of upper-tropospheric temperature and hence reduced land-sea thermal contrast in the Late Pliocene experiment with the PlioMIP SSTs relative to 

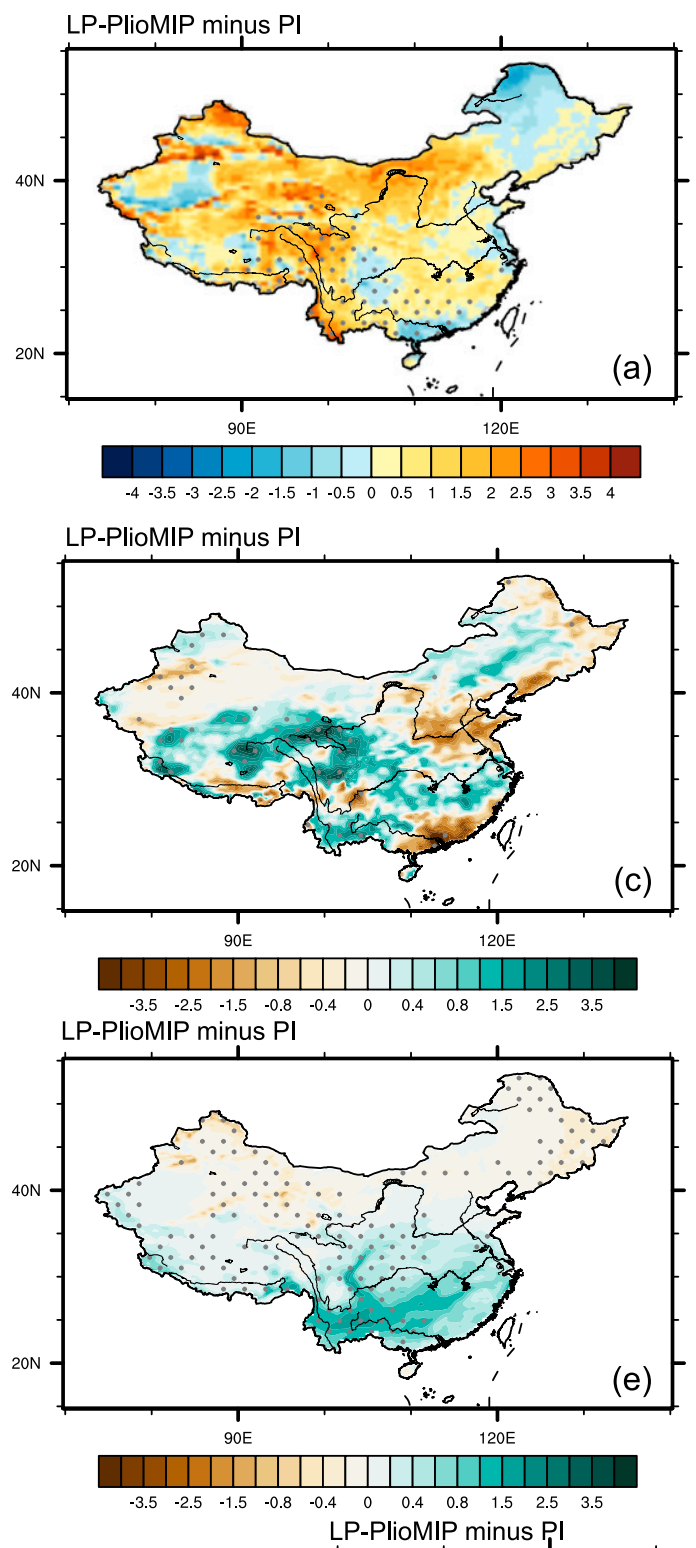

LP-PlioMIP minus LP-PRISM4

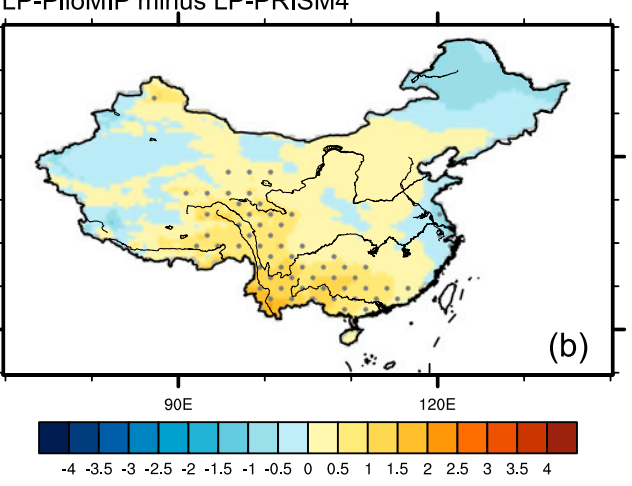

LP-PlioMIP minus LP-PRISM4

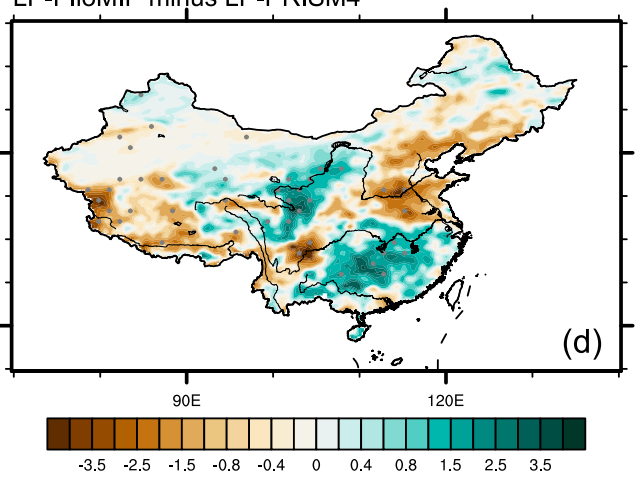

LP-PlioMIP minus LP-PRISM4

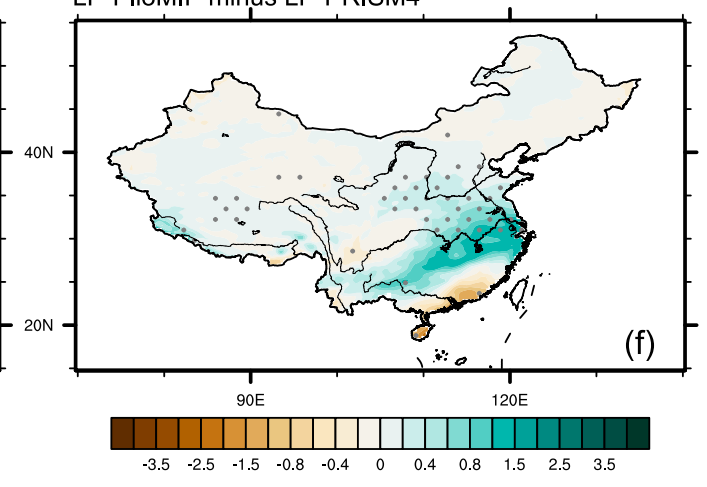

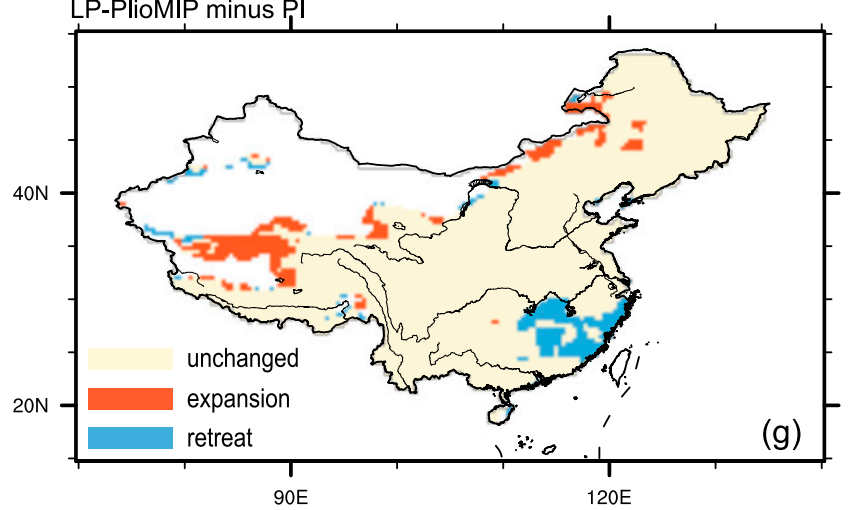

FIG. 11. Differences in (a),(b) annual mean surface air temperature $\left({ }^{\circ} \mathrm{C}\right),(\mathrm{c}),(\mathrm{d})$ summer precipitation $\left(\mathrm{mm} \mathrm{day}^{-1}\right)$, and (e),(f) winter precipitation $\left(\mathrm{mm} \mathrm{day}^{-1}\right)$ between (a),(c),(e) the Late Pliocene experiment forced by the PlioMIP-based SSTs and preindustrial run and (b),(d),(f) the Late Pliocene experiment with the PRISM4based SSTs. Areas that pass 95\%-level-of-significance test are dotted. (g) Differences in East Asian monsoon domain between the Late Pliocene with the PlioMIP-based SSTs and preindustrial. 

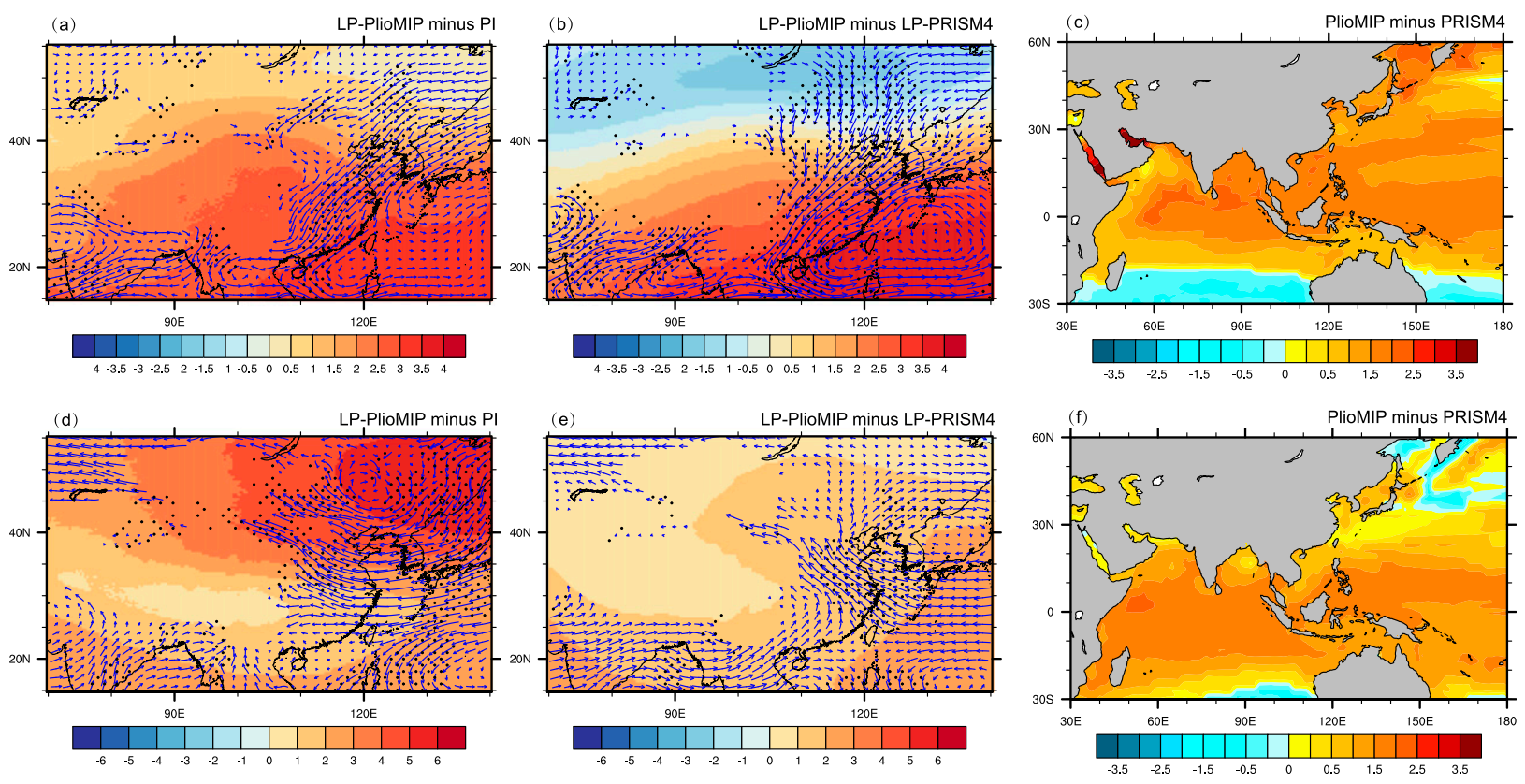

FIG. 12. Differences in (a),(b) summer winds at $850 \mathrm{hPa}\left(\mathrm{m} \mathrm{s}^{-1}\right)$ and (d),(e) winter winds at $850 \mathrm{hPa}\left(\mathrm{m} \mathrm{s}^{-1}\right)$ between (left) the Late Pliocene experiment forced by the PlioMIP-based SSTs and the preindustrial run, and (middle) the Late Pliocene experiment with the PRISM4-based SSTs. Shading shows the anomalies of mean upper-tropospheric (500-200 hPa) temperature $\left({ }^{\circ} \mathrm{C}\right)$. Areas where meridional wind passes $95 \%$-level of-significance test are dotted. (right) Differences between the PlioMIP model-based and PRISM4-based SSTs $\left({ }^{\circ} \mathrm{C}\right)$ in (c) summer and (f) winter.

the one with the PRISM4 SSTs, which in turn results in a northerly anomaly (Figs. 12a-c). The anomalous northerly is unfavorable for water vapor transport from the tropical ocean to the midlatitudes, leading to less (more) precipitation over northern (southern) China in response to the PlioMIP SSTs than to the PRISM4 SSTs (Fig. 11d). Moreover, temperature over southwest China is higher in the experiment with the PlioMIP SSTs than with the PRISM4 SSTs (Fig. 11b), which may be partly attributed to the reduced precipitation over there and the associated change in total cloud amount. The decrease in precipitation is closely tied to the anomalous northerly over that region.

The East Asian winter monsoon is weakened in the Late Pliocene in response to either the PlioMIP model or PRISM4-based SSTs, but it gets much weaker when forced by the PlioMIP SSTs (Figs. 12d,e). Compared with the experiment forced by the PRISM4 SSTs, there is a southeasterly anomaly over northern China in winter in the experiment with the PlioMIP SSTs (Fig. 12e). This wind anomaly is associated with the anomalous anticyclonic over northeast China, which may be partly attributed to the warmer temperature over the Sea of Japan in the PlioMIP-based forcing (Fig. 12f). Moreover, the anomalous southeasterly leads to enhanced precipitation over Yangtze River via transporting more water vapor from western North Pacific to that region
(Fig. 11f). The aforementioned results indicate a dominant role of SSTs in regulating the variation of East Asian monsoon in the Late Pliocene, which is supported by previous studies (Yan et al. 2012a; Zhang et al. 2015) and could be further validated using the CCAM4 forced by the PlioMIP-based SSTs in the future.

\section{b. Model horizontal resolution}

The qualitative comparisons show that both the HCAM4 and CCAM4 predict a warmer condition with higher precipitation over China in the Late Pliocene, but the difference in spatial distribution remains considerable (Figs. 6a, 13b). A notable difference in precipitation change is found over the midwestern part of China, with enhanced precipitation in the HCAM4 (Fig. 6a) but decreased precipitation in the CCAM4 (Fig. 13b). Note that the CCAM4 predicts a virtual precipitation center over that region due to the coarse horizontal resolution (Fig. 3f). This bias may contribute to the aforementioned discrepancy between the HCAM4 and CCAM4. Differences are also observed over northwest China where the HCAM4 predicts less precipitation whereas the CCAM4 gives more precipitation. This discrepancy may be partially attributed to the difference in depicting the circulation systems along the eastern and western boundary of the Tibetan Plateau between the two models (Fig. 4). 

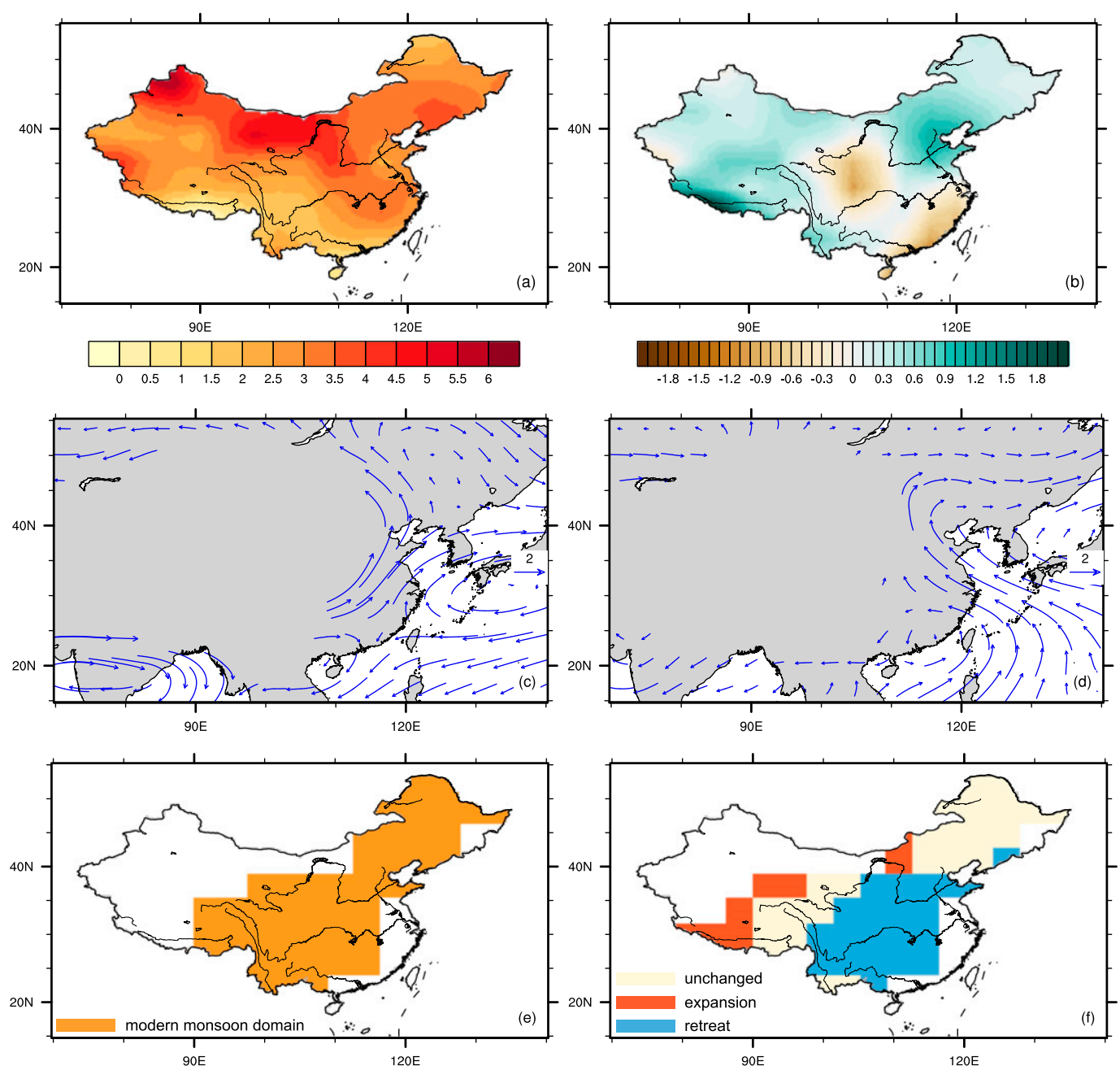

FIG. 13. Differences in (a) annual mean surface air temperature $\left({ }^{\circ} \mathrm{C}\right),(\mathrm{b})$ annual mean precipitation $\left(\mathrm{mm} \mathrm{day}^{-1}\right)$, (c) summer winds at $850 \mathrm{hPa}\left(\mathrm{m} \mathrm{s}^{-1}\right)$, and (d) winter winds at $850 \mathrm{hPa}\left(\mathrm{m} \mathrm{s}^{-1}\right)$ between the Late Pliocene experiment forced by the PRISM3-based SSTs and the preindustrial run with the CCAM4. Areas that pass 95\%-level-ofsignificance test are dotted. Also shown are (e) the simulated East Asian monsoon domain in the preindustrial and (f) its change in the Late Pliocene with the CCAM4.

The largest discrepancy in temperature change is found over southwest China, with cooling in the HCAM4 (Fig. 5a) but warming in the CCAM4 (Fig. 13a). This discrepancy is also seen in the other PlioMIP models (Zhang et al. 2013) and may result from the differences in 1) the aforementioned precipitation change (i.e., local total cloud amount) and 2) the boundary conditions. The PRISM4 and PRISM3 boundary conditions are employed in the HCAM4 and CCAM4, respectively. The topographies are $\sim 600-1000 \mathrm{~m}$ higher over southwest China in the PRISM4 reconstruction relative to the PRISM3 (Fig. 2c), hence contributing to lower temperature in the HCAM4 due to the lapse-rate effect.

For the monsoonal circulations, both the HCAM4 and CCAM4 indicate an enhanced East Asian summer monsoon and a weakened winter monsoon in the Late
Pliocene (Figs. 8, 13). Although the CCAM4 shows a northwestward shift of East Asian monsoon boundary in the Late Pliocene (Fig. 13f), the monsoon domain is greatly retreated over east China due to reduced precipitation, which may be overestimated given the poor performance of the CCAM4 in simulating precipitation over China (Fig. 3) and the present-day monsoon domain (Fig. 13e).

\section{Discussion}

\section{a. Data-model comparisons}

Figure 14 shows a preliminary synthesis of the reconstructed climate change over China in the Late Pliocene. The Late Pliocene warming suggested by multiproxies is 


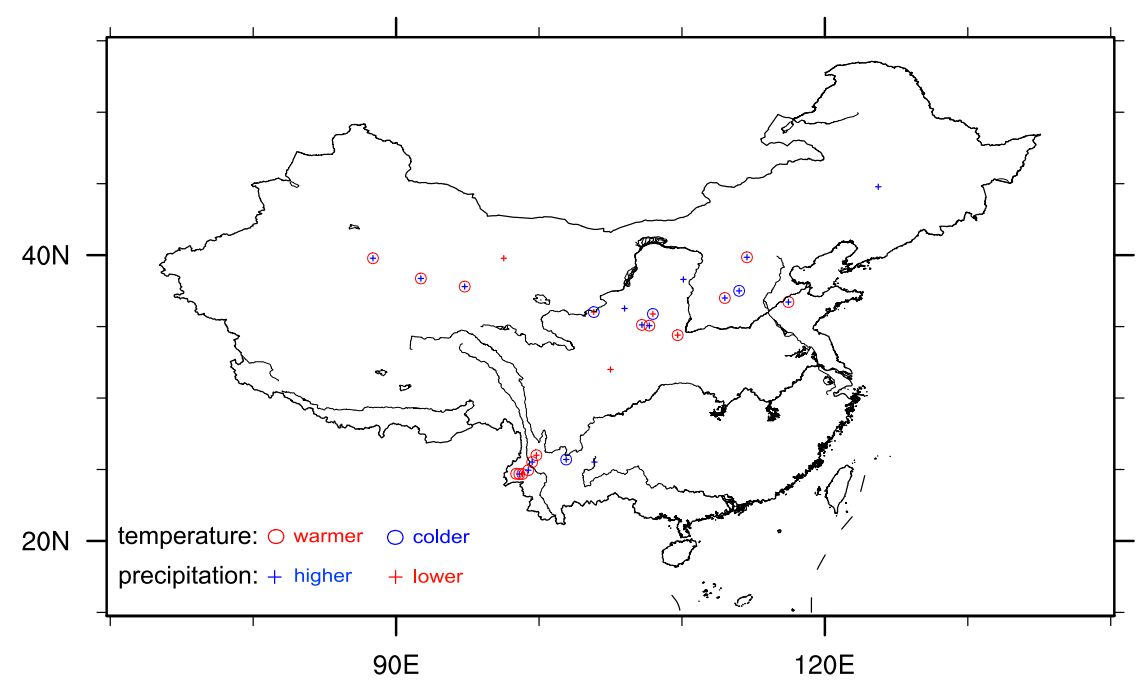

FIG. 14. Preliminary compilation of the reconstructed temperature and precipitation change over China in the Late Pliocene (Table 2).

generally captured in both the HCAM4 and CCAM4 experiments. Although temperature proxies are scarce over southeast China, the simulated cooling in the HCAM4 simulation (forced by the PRISM4-based SSTs) is partially supported by the record at Yuanmou $\left(\sim 25.7^{\circ} \mathrm{N}, 101.9^{\circ} \mathrm{E}\right)$ (Table 2). For the Late Pliocene precipitation, the reconstructed increase in precipitation over the lower reaches of Yellow River is only observed in the simulations with the PRISM4-based SSTs. However, only the CCAM4 captures the increased precipitation over northwest China (e.g., Qiadam basin). In addition, all the simulations produce enhanced precipitation over southwest China as suggested by pollen and fossil records (e.g., Su et al. 2013). It should be noted that pollen-based reconstructions may be biased to seasonal temperature instead of annual mean in some cases, and higher precipitation does not necessarily indicate wetter climate owing to the effect of evaporation (e.g., Ji et al. 2017). These limitations may introduce additional uncertainty in detailed model-data comparisons.

Geological evidence indicates a stronger (weaker) summer (winter) monsoon in the Late Pliocene (e.g., Zheng et al. 2004; Nie et al. 2007, 2014), which is only observed in the simulations driven by the PRISM4based SSTs. This result indicates that the PRISM4based SSTs may be, to some extent, more reliable than the PlioMIP-based SSTs. This inference is supported by the evaluation of the modeled changes in the midlatitude westerly and Indian summer monsoon. Proxies indicate that the midlatitude westerly became weaker in the Late Pliocene (Rea et al. 1998) and the Indian summer monsoon was intensified (Singh et al. 2012). These features are well captured by the HCAM4 with the PRISM4-based SSTs, but not with the PlioMIP modelbased SSTs (see Fig. S1 in the online supplemental material). However, we acknowledge that the modeldata mismatch with the PlioMIP SSTs may result from missing external forcings and/or physics in the model. Given the complexity of the climate system and different model sensitivities, a comprehensive assignment should be carried out in the future to obtain a more robust conclusion as to the relative accuracy of different Pliocene SST distributions.

\section{b. Implications}

Geological evidence and model results from HCAM4 and PlioMIP consistently show a stronger (weaker) summer (winter) monsoon circulation, so we hypothesize that the East Asian monsoon circulation in future may tend to develop toward the state in the Late Pliocene warm period. This is confirmed by the projected East Asian monsoon changes in the twenty-first century based on the multimodel ensemble mean (e.g., Jiang and Tian 2013). In addition, all the model results here imply that China may be warmer and experience more precipitation in the Late Pliocene (albeit with regional differences), which is in close agreement with future projections (Christensen et al. 2013).

However, there are obvious differences between the Late Pliocene and the twenty-first-century warming world in terms of external forcings and time scale we considered. The Late Pliocene climate change is attributed to changes in atmospheric $\mathrm{CO}_{2}$ concentration, ice sheets, vegetation, and topography, whereas the main forcing in future projections is the increased greenhouse gases. On the other hand, we focus on the equilibrium climate response in the Late Pliocene, whereas transient response is investigated in future projections. It should be noted that polar ice sheets may be largely melted 
TABLE 2. Reconstructed temperature and precipitation change in the Late Pliocene. MAT: mean annual temperature; MWMT: mean warmest monthly temperature; MCMT: mean coldest monthly temperature; MAP: mean annual precipitation; and GSP: growing season precipitation.

\begin{tabular}{|c|c|c|c|c|c|c|}
\hline Location & $\begin{array}{l}\text { Lat } \\
\left({ }^{\circ} \mathrm{N}\right)\end{array}$ & $\begin{array}{l}\text { Lon } \\
\left({ }^{\circ} \mathrm{E}\right)\end{array}$ & Proxies & Temperature & Precipitation & Reference \\
\hline Sikouzi & 36.267 & 105.983 & Pollen & - & Higher & $\begin{array}{l}\text { Jiang and Ding } \\
\text { (2008) }\end{array}$ \\
\hline Chaona & 35.117 & 107.2 & Pollen & Warmer & Higher & Wu et al. (2007) \\
\hline Jiaxian & 38.3 & 110.1 & Heavy mineral & - & Higher & Peng et al. (2018) \\
\hline Qaidam basin & 38.367 & 91.733 & Pollen & Warmer & Higher & Cai et al. (2012) \\
\hline Qaidam basin & 37.8 & 94.8 & Pollen & Warmer & Higher & Wu et al. (2011) \\
\hline Yushe & 37 & 113 & Fruits, seeds & Warmer & Higher & Liu et al. (2002) \\
\hline $\begin{array}{l}\text { Taigu and } \\
\text { Yushe }\end{array}$ & 37.5 & 114 & Pollen & Colder $\left(T_{\text {MAT }}:-2^{\circ}\right.$ to $\left.6^{\circ} \mathrm{C}\right)$ & Higher & Li et al. (2004) \\
\hline Shijiawan & 34.4 & 109.7 & Pollen & Warmer & Lower & Han et al. (1997) \\
\hline Xifeng & 35.883 & 107.967 & Molluscan & Colder & Lower & Wu et al. (2006) \\
\hline Lingtai & 35.067 & 107.717 & Pollen & Warmer & Higher & Wu (2001) \\
\hline Yuanmou & 25.7 & 101.9 & Fossil wood & Colder $\left(T_{\text {MAT }}:-4.5^{\circ}\right.$ to $\left.5.8^{\circ} \mathrm{C}\right)$ & $\begin{array}{l}\text { Higher }\left(P_{\text {MAP: }}:\right. \\
\quad+878-1020 \mathrm{~mm})\end{array}$ & Yao et al. (2012) \\
\hline Zhanqiu & 36.717 & 117.45 & Pollen & Warmer & Higher & Wang et al. (2002) \\
\hline LopNur & 39.783 & 88.383 & Pollen & $\begin{array}{l}\text { Warmer }\left(T_{\mathrm{MAT}}:+1.9^{\circ} \mathrm{C} ;\right. \\
T_{\mathrm{MWMT}}:+7.0^{\circ} \mathrm{C} \\
\left.T_{\mathrm{MCMT}}:+5.9^{\circ} \mathrm{C}\right)\end{array}$ & Higher $\left(P_{\mathrm{MAP}}:+973 \mathrm{~mm}\right)$ & Hao et al. (2012) \\
\hline Eastern China & 32 & 105 & Fossil mammals & - & Lower & $\begin{array}{l}\text { Eronen et al. } \\
\qquad(2010)\end{array}$ \\
\hline Tuantian & 24.683 & 98.617 & Fossil leaves & $\begin{array}{c}\text { Warmer }\left(T_{\mathrm{MAT}}:+2.3^{\circ} \mathrm{C}\right. \\
T_{\mathrm{MWMT}}:+4.1^{\circ} \mathrm{C} \\
\left.T_{\mathrm{MCMT}}:-0.7^{\circ} \mathrm{C}\right)\end{array}$ & Lower $\left(P_{\text {MAP }}:-209 \mathrm{~mm}\right)$ & Xie et al. (2012) \\
\hline Tengchong & 24.7 & 98.4 & Fossil plants & Warmer $\left(T_{\mathrm{MAT}}:+3.5^{\circ} \mathrm{C}\right)$ & Lower ( $\left.P_{\text {MAP }}:-67 \mathrm{~mm}\right)$ & Sun et al. (2011) \\
\hline Eryuan & 26 & 99.817 & Pollen & Warmer $\left(T_{\mathrm{MAT}}:+1.8^{\circ} \mathrm{C}\right)$ & Higher ( $\left.P_{\mathrm{MAP}}:+5 \mathrm{~mm}\right)$ & Sun et al. (2011) \\
\hline Yangyi & 24.95 & 99.25 & Pollen & Warmer $\left(T_{\mathrm{MAT}}:+1.6^{\circ} \mathrm{C}\right)$ & Higher $\left(P_{\mathrm{MAP}}:+60 \mathrm{~mm}\right)$ & Sun et al. (2011) \\
\hline Longling & 24.683 & 98.833 & Pollen & Warmer $\left(T_{\mathrm{MAT}}:+5.5^{\circ} \mathrm{C}\right)$ & Lower ( $\left.P_{\text {MAP: }}-1087 \mathrm{~mm}\right)$ & Kou et al. (2006) \\
\hline Longmen & 25.52 & 99.52 & Pollen & $\begin{array}{c}\text { Warmer }\left(T_{\mathrm{MAT}:+1.5^{\circ} \mathrm{C}}\right. \\
T_{\mathrm{MWMT}}:+4.4^{\circ} \mathrm{C} \\
\left.T_{\mathrm{MCMT}}:+0.7^{\circ} \mathrm{C}\right)\end{array}$ & Higher $\left(P_{\mathrm{GSP}}:+749 \mathrm{~mm}\right)$ & Su et al. (2013) \\
\hline Jiuxi basin & 39.783 & 97.533 & Pollen & - & Lower & Ma et al. (2005) \\
\hline Gaolanshan & 36.017 & 103.833 & Aeolian sediment & Colder & Lower & Zhang et al. (2010) \\
\hline Weixian & 39.85 & 114.55 & $\begin{array}{l}\text { Micropaleontological } \\
\text { fossil }\end{array}$ & Warmer & Higher & Pang et al. (2015) \\
\hline Qianan & 44.783 & 123.733 & Pollen & - & Higher & Jia et al. (1989) \\
\hline Qujing & 25.52 & 103.88 & Pollen and spores & - & Higher & $\begin{array}{l}\text { Wang and Shu } \\
\text { (2004) }\end{array}$ \\
\hline
\end{tabular}

in the future in response to elevated levels of $\mathrm{CO}_{2}$ concentration in an equilibrium state (Huybrechts et al. 2011; Yan et al. 2014), with a northward shift of vegetation zones (e.g., Hickler et al. 2012). This result indicates that the reconstructed changes in ice sheets and vegetation in the Late Pliocene may also occur in future on a longer time scale (i.e., millennia). Thus, the Late Pliocene may be more appropriate to serve as a potential analog for future warming world in terms of equilibrium climate response.

\section{Conclusions}

In this study, we investigate climate change over China during the Late Pliocene warm period using a 25-km resolution CAM4, and explore the sensitivity of climate change to the Late Pliocene SST forcings and model horizontal resolution. This investigation is helpful to improve our understanding on Late Pliocene climate over China. The main results are summarized as follows:

1) The HCAM4 performs well in reproducing observed spatial patterns of the present-day temperature, precipitation, and low-level wind fields over China. It obviously reduces the biases seen in a coarse-resolution model and provides more local information.

2) The HCAM4 simulations indicate a warmer climate with increased precipitation over China in the Late Pliocene relative to the preindustrial. The annual mean temperature and precipitation are increased 
by $\sim 0.5^{\circ} \mathrm{C}$ and $0.4 \mathrm{~mm} \mathrm{day}^{-1}$, respectively, in the Late Pliocene. For the spatial pattern, the majority of China experiences significant warming in the Late Pliocene with the exception of southwest China where the temperature is decreased. Annual mean precipitation is enhanced mainly over the Tibetan Plateau, south and central China, and parts of northeast China, but the spatial pattern of precipitation anomaly varies by season.

3) The East Asian summer monsoon is intensified in the Late Pliocene, with a westward (northward) shift of the WNPSH (EAWJ). The East Asian winter monsoon is weakened, with a weaker East Asian trough and a southward shift of the EAWJ. Changes in monsoon circulations are essentially attributed to the enhanced (reduced) land-sea thermal contrast in summer (winter). Additionally, the East Asian monsoon domain exhibits a northwestward expansion in the Late Pliocene, especially over the Tibetan Plateau.

4) The simulated climate change is sensitive to the Late Pliocene SST forcings and model horizontal resolution. Different SST forcings (i.e., from PRISM4 and PlioMIP) largely affect the simulated summer and winter monsoon circulations and the associated precipitation changes, particularly the summer monsoon in terms of phase change. Model horizontal resolution mainly has impact on the simulated precipitation change but shows little influence on monsoonal circulations.

Acknowledgments. Many thanks to the editor and three anonymous reviewers for their very constructive and useful comments in helping to improve our manuscript. We thank the PRISM4 and PlioMIP groups for producing and making available their outputs. We thank R. Zhang and X.F. Huang for help on the compilation of proxies over China. This study was jointly funded by the National Key Research and Development Program of China (2016YFA0602704), the National Natural Science Foundation of China (41772179, 41505068, and 41472160), the Thousand Talents Program for Distinguished Young Scholars (for Z. S. Zhang), and the Young Elite Scientists Sponsorship Program by CAST (2017QNRC001). The high-resolution CAM4 data are freely available upon request.

\section{REFERENCES}

Cai, M. T., X. M. Fang, F. L. Wu, Y. F. Miao, and E. Appel, 2012: Pliocene-Pleistocene stepwise drying of central Asia: Evidence from paleomagnetism and sporopollen record of the deep borehole SG-3 in the western Qaidam Basin, NE Tibetan Plateau. Global Planet. Change, 94-95, 72-81, https://doi.org/ 10.1016/j.gloplacha.2012.07.002.
Cane, M. A., and P. Molnar, 2001: Closing of the Indonesian seaway as a precursor to east African aridification around 3-4 million years ago. Nature, 411, 157-162, https://doi.org/ $10.1038 / 35075500$.

Chen, H., and J. Sun, 2013: Projected change in East Asian summer monsoon precipitation under RCP scenario. Meteor. Atmos. Phys., 121, 55-77, https://doi.org/10.1007/s00703-013-0257-5.

,$- \ldots$, and X. Chen, 2014: Projection and uncertainty analysis of global precipitation-related extremes using CMIP5 models. Int. J. Climatol., 34, 2730-2748, https://doi.org/10.1002/joc.3871.

Christensen, J. H., and Coauthors, 2013: Climate phenomena and their relevance for future regional climate change. Climate Change 2013: The Physical Science Basis, T. F. Stocker et al., Eds., Cambridge University Press, 1217-1308.

Dee, D. P., and Coauthors, 2011: The ERA-Interim reanalysis: Configuration and performance of the data assimilation system. Quart. J. Roy. Meteor. Soc., 137, 553-597, https://doi.org/10.1002/qj.828.

Ding, Y., and J. C. L. Chan, 2005: The East Asian summer monsoon: An overview. Meteor. Atmos. Phys., 89, 117-142, https:// doi.org/10.1007/s00703-005-0125-z.

Dolan, A., and Coauthors, 2015: Using results from the PlioMIP ensemble to investigate the Greenland Ice Sheet during the warm Pliocene. Climate Past, 11, 403-424, https://doi.org/ 10.5194/cp-11-403-2015.

Dowsett, H., T. M. Cronin, R. Z. Poore, R. S. Thompson, R. C. Whatley, and A. M. Wood, 1992: Micropaleontological evidence for increased meridional heat transport in the North Atlantic Ocean during the Pliocene. Science, 258, 1133-1135, https://doi.org/10.1126/science.258.5085.1133.

- and Coauthors, 1994: Joint investigations of the Middle Pliocene climate I: PRISM paleoenvironmental reconstructions. Global Planet. Change, 9, 169-195, https://doi.org/10.1016/ 0921-8181(94)90015-9.

— J. A. Barron, R. Z. Poore, R. S. Thompson, T. M. Cronin, S. E. Ishman, and D. A. Willard, 1999: Middle Pliocene paleoenvironmental reconstruction: PRISM2. USGS Open-File Rep. 99-535, https://doi.org/10.3133/ofr99535.

- M. M. Robinson, and K. M. Foley, 2009: Pliocene threedimensional global ocean temperature reconstruction. Climate Past, 5, 769-783, https://doi.org/10.5194/cp-5-769-2009.

, and Coauthors, 2010: The PRISM3D paleoenvironmental reconstruction. Stratigraphy, 7, 123-139.

_- and Coauthors, 2012: Assessing confidence in Pliocene sea surface temperatures to evaluate predictive models. Nat. Climate Change, 2, 365-371, https://doi.org/10.1038/ nclimate1455.

— , and Coauthors, 2013: Sea surface temperature of the midPiacenzian ocean: A data-model comparison. Sci. Rep., 3, 2013, https://doi.org/10.1038/srep02013.

, and Coauthors, 2016: The PRISM4 (mid-Piacenzian) palaeoenvironmental reconstruction. Climate Past, 12, 1519-1538, https://doi.org/10.5194/cp-12-1519-2016.

Eronen, J. T., K. Puolamaki, L. Liu, K. Lintulaakso, J. Damuth, C. Janis, and M. Fortelius, 2010: Precipitation and large herbivorous mammals II: Application to fossil data. Evol. Ecol. Res., 12, 235-248, http://www.evolutionary-ecology.com/abstracts/ v12/2539.html.

Gao, X., Y. Xu, Z. Zhao, S. J. Pal, and F. Giorgi, 2006: On the role of resolution and topography in the simulation of East Asia precipitation. Theor. Appl. Climatol., 86, 173-185, https:// doi.org/10.1007/s00704-005-0214-4.

, Y. Shi, R. Song, F. Giorgi, Y. Wang, and D. Zhang, 2008: Reduction of future monsoon precipitation over China: 
Comparison between a high resolution RCM simulation and the driving GCM. Meteor. Atmos. Phys., 100, 73-86, https://doi.org/10.1007/s00703-008-0296-5.

,$- \ldots$, and F. Giorgi, 2011: A high resolution simulation of climate change over China. Sci. China Earth Sci., 54, 462-472, https://doi.org/10.1007/s11430-010-4035-7.

Han, J., W. S. Fyfe, F. J. Longstaffe, H. C. Palmer, F. H. Yan, and X. S. Mai, 1997: Pliocene-Pleistocene climatic change recorded in fluviolacustrine sediments in central China. Palaeogeogr. Palaeoclimatol. Palaeoecol., 135, 27-39, https://doi.org/10.1016/ S0031-0182(97)00019-9.

Hao, H., D. K. Ferguson, H. Chang, and C. S. Li, 2012: Vegetation and climate of the Lop Nur area, China, during the past 7 million years. Climatic Change, 113, 323-338, https://doi.org/ 10.1007/s10584-011-0347-7.

Haywood, A. M., P. J. Valdes, and B. W. Sellwood, 2000: Global scale palaeoclimate reconstruction of the middle Pliocene climate using the UKMO GCM: Initial results. Global Planet. Change, 25, 239-256, https://doi.org/10.1016/S0921-8181 (00)00028-X.

, and Coauthors, 2010: Pliocene Model Intercomparison Project (PlioMIP): Experimental design and boundary conditions (Experiment 1). Geosci. Model Dev., 3, 227-242, https://doi.org/ 10.5194/gmd-3-227-2010.

, H. J. Dowsett, M. M. Robinson, D. K. Stoll, A. M. Dolan, D. L. Lunt, B. Otto-Bliesner, and M. A. Chandler, 2011: Pliocene Model Intercomparison Project (PlioMIP): Experimental design and boundary conditions (Experiment 2). Geosci. Model Dev., 4, 571-577, https://doi.org/10.5194/gmd-4-571-2011.

, and Coauthors, 2013: Large-scale features of Pliocene climate: Results from the Pliocene Model Intercomparison Project. Climate Past, 9, 191-209, https://doi.org/10.5194/cp-9-191-2013.

—-, H. J. Dowsett, and A. M. Dolan, 2016a: Integrating geological archives and climate models for the mid-Pliocene warm period. Nat. Commun., 7, 10646, https://doi.org/10.1038/ ncomms10646.

- and Coauthors, 2016b: The Pliocene Model Intercomparison Project (PlioMIP) Phase 2: Scientific objectives and experimental design. Climate Past, 12, 663-675, https://doi.org/ 10.5194/cp-12-663-2016.

He, S., and H. Wang, 2012: An integrated East Asian winter monsoon index and its interannual variability (in Chinese). Chin. J. Atmos. Sci., 36, 523-538.

Hickler, T., and Coauthors, 2012: Projecting the future distribution of European potential natural vegetation zones with a generalized, tree species-based dynamic vegetation model. Global Ecol. Biogeogr., 21, 50-63, https://doi.org/10.1111/ j.1466-8238.2010.00613.x.

Hill, D., and Coauthors, 2014: Evaluating the dominant components of warming in Pliocene climate simulations. Climate Past, 10, 79-90, https://doi.org/10.5194/cp-10-79-2014.

Hurrell, J. W., J. J. Hack, D. Shea, J. M. Caron, and J. Rosinski, 2008: A new sea surface temperature and sea ice boundary dataset for the Community Atmosphere Model. J. Climate, 21, 5145-5153, https://doi.org/10.1175/2008JCLI2292.1.

Huybrechts, P., H. Goelzer, I. Janssens, E. Driesschaert, T. Fichefet, H. Goosse, and M.-F. Loutre, 2011: Response of the Greenland and Antarctic ice sheets to multi-millennial greenhouse warming in the Earth system model of intermediate complexity LOVECLIM. Surv. Geophys., 32, 397-416, https://doi.org/ 10.1007/s10712-011-9131-5.

Ji, S., J. Nie, D. O. Breecker, Z. Luo, and Y. Song, 2017: Intensified aridity in northern China during the middle Piacenzian warm period. J. Asian Earth Sci., 147, 222-225, https://doi.org/10.1016/ j.jseaes.2017.07.016.

Jia, C. H., L. Yu, N. Du, and Z. Kong, 1989: Changes of vegetation and climate in Qian An County, Jilin Province since late Tertiary (in Chinese). Dili Kexue, 9, 274-282.

Jiang, D., and Z. P. Tian, 2013: East Asian monsoon change for the 21st century: Results of CMIP3 and CMIP5 models. Chin. Sci. Bull., 58, 1427-1435, https://doi.org/10.1007/s11434-012-5533-0.

_ - H. Wang, Z. Ding, X. Lang, and H. Drange, 2005: Modeling the middle Pliocene climate with a global atmospheric general circulation model. J. Geophys. Res., 110, D14107, https://doi.org/ 10.1029/2004JD005639.

Jiang, H. C., and Z. L. Ding, 2008: A 20 Ma pollen record of EastAsian summer monsoon evolution from Guyuan, Ningxia, China. Palaeogeogr. Palaeoclimatol. Palaeoecol., 265, 30-38, https://doi.org/10.1016/j.palaeo.2008.04.016.

Karas, C., D. Nürnberg, A. Bahr, J. Groeneveld, J. O. Herrle, R. Tiedemann, and P. B. deMenocal, 2017: Pliocene oceanic seaways and global climate. Sci. Rep., 7, 39842, https://doi.org/ 10.1038/srep39842.

Kou, X.-Y., D. K. Ferguson, J. X. Xu, Y. F. Wang, and C.-S. Li, 2006: The reconstruction of paleovegetation and paleoclimate in the Late Pliocene of west Yunnan, China. Climatic Change, 77, 431-448, https://doi.org/10.1007/ s10584-005-9039-5.

Lee, J. Y., and B. Wang, 2014: Future change of global monsoon in the CMIP5. Climate Dyn., 42, 101-119, https://doi.org/10.1007/ s00382-012-1564-0.

Li, J., R. Yu, W. Yuan, H. Chen, W. Sun, and Y. Zhang, 2015: Precipitation over East Asia simulated by NCAR CAM5 at different horizontal resolutions. J. Adv. Model. Earth Syst., 7, 774-790, https://doi.org/10.1002/2014MS000414.

Li, X. Q., C. S. Li, H. Y. Lu, J. R. Dodson, and Y. F. Wang, 2004: Paleovegetation and paleoclimate in middle-late Pliocene, Shanxi, central China. Palaeogeogr. Palaeoclimataol. Palaeoecol., 210, 57-66, https://doi.org/10.1016/j.palaeo.2004.03.007.

Liu, G. W., E. B. Leopold, Y. Liu, W. M. Wang, Z. Y. Yu, and G. B. Tong, 2002: Palynological record of Pliocene climate events in North China. Rev. Palaeobot. Palynol., 119, 335-340, https:// doi.org/10.1016/S0034-6667(01)00125-7.

Lu, R., and B. Dong, 2001: Westward extension of North Pacific subtropical high in summer. J. Meteor. Soc. Japan, 79, 12291241, https://doi.org/10.2151/jmsj.79.1229.

Lunt, D. J., A. M. Haywood, G. A. Schmidt, U. Salzmann, P. J. Valdes, and H. J. Dowsett, 2010: Earth system sensitivity inferred from Pliocene modelling and data. Nat. Geosci., $\mathbf{3}$, 60-64, https://doi.org/10.1038/ngeo706.

Ma, Y., X. Fang, J. Li, F. Wu, and J. Zhang, 2005: The vegetation and climate change during Neocene and Early Quaternary in Jiuxi Basin, China. Sci. China, 48D, 676-688, https://doi.org/ 10.1360/03yd0110.

Man, W., T. Zhou, and J. H. Jungclaus, 2012: Simulation of the East Asian summer monsoon during the last millennium with the MPI Earth system model. J. Climate, 25, 7852-7866, https:// doi.org/10.1175/JCLI-D-11-00462.1.

Naish, T., and Coauthors, 2009: Obliquity-paced Pliocene West Antarctic ice sheet oscillations. Nature, 458, 322-328, https:// doi.org/10.1038/nature07867.

Neale, R., and Coauthors, 2010: Description of the NCAR Community Atmosphere Model (CAM 4.0). NCAR Tech. Note NCAR/TN-486-STR, 268 pp.

Nie, J., J. W. King, and X. Fang, 2007: Enhancement mechanisms of magnetic susceptibility in the Chinese red-clay sequence. 
Geophys. Res. Lett., 34, L19705, https://doi.org/10.1029/ 2007GL031430.

— - T. Stevens, Y. Song, J. W. King, R. Zhang, S. Ji, L. S. Gong, and D. Cares, 2014: Pacific freshening drives Pliocene cooling and Asian monsoon intensification. Sci. Rep., 4, 5474, https:// doi.org/10.1038/srep05474.

— , and Coauthors, 2017: Dominant 100,000-year precipitation cyclicity in a late Miocene lake from northeast Tibet. Sci. $A d v$., 3, e1600762, https://doi.org/10.1126/sciadv.1600762.

- A. Pullen, C. N. Garzione, W. Peng, and Z. Wang, 2018: PreQuaternary decoupling between Asian aridification and high dust accumulation rates. Sci. $A d v$., 4, eaao6977, https://doi.org/ 10.1126/sciadv.aao6977.

O’Brien, C. L., G. L. Foster, M. A. Martínez-Botí, R. Abell, J. W. B. Rae, and R. D. Pancost, 2014: High sea surface temperatures in tropical warm pools during the Pliocene. Nat. Geosci., 7, 606-611, https://doi.org/10.1038/ngeo2194.

Pang, Q., D. Zhai, Z. Zhao, and Z. Zhang, 2015: Late Cenozoic micropalaeontology in the Nihewan Basin and its implications for environmental evolution (in Chinese). Acta Geol. Sin., 89, 817-842.

Peng, W., J. Nie, Z. Wang, X. Qiang, E. Garzanti, K. Pfaff, Y. Song, and T. Stevens, 2018: A major change in precipitation gradient on the Chinese Loess Plateau at the PlioceneQuaternary boundary. J. Asian Earth Sci., 155, 134-138, https://doi.org/10.1016/j.jseaes.2017.10.031.

Rea, D. K., H. Snoeckx, and L. H. Joseph, 1998: Late Cenozoic eolian deposition in the North Pacific: Asian drying, Tibetan uplift, and cooling of the Northern Hemisphere. Paleoceanography, 13, 215-224, https://doi.org/10.1029/98PA00123.

Salzmann, U., A. M. Haywood, D. Lunt, P. Valdes, and D. Hill, 2008: A new global biome reconstruction and data-model comparison for the middle Pliocene. Global Ecol. Biogeogr., 17, 432-447, https://doi.org/10.1111/j.1466-8238.2008.00381.x.

_ restrial warming revealed by data-model discord. Nat. Climate Change, 3, 969-974, https://doi.org/10.1038/nclimate2008.

Simmonds, I., 1985: Analysis of the "spinup" of a general circulation model. J. Geophys. Res., 90, 5637-5660, https://doi.org/ 10.1029/JD090iD03p05637.

Singh, S., B. Parkash, A. K. Awasthi, and T. Singh, 2012: Palaeoprecipitation record using $\mathrm{O}$-isotope studies of the $\mathrm{Hi}$ malayan foreland basin sediments, NW India. Palaeogeogr. Palaeoclimatol. Palaeoecol., 331-332, 39-49, https://doi.org/ 10.1016/j.palaeo.2012.02.031.

Su, T., F. M. B. Jacques, R. A. Spicer, Y. S. Liu, Y. J. Huang, Y. W. Xing, and Z. K. Zhou, 2013: Post-Pliocene establishment of the present monsoonal climate in SW China: Evidence from the late Pliocene Longmen megaflora. Climate Past, 9, 19111920, https://doi.org/10.5194/cp-9-1911-2013.

Sun, B.-N., J.-Y. Wu, Y.-S. Liu, S.-T. Ding, X.-C. Li, S.-P. Xie, D.-F. Yan, and Z.-C. Lin, 2011: Reconstructing Neogene vegetation and climates to infer tectonic uplift in western Yunnan, China. Palaeogeogr. Palaeoclimatol. Palaeoecol., 304, 328-336, https://doi.org/10.1016/j.palaeo.2010.09.023.

Sun, Y., T. Zhou, G. Ramstein, C. Contoux, and Z. Zhang, 2016: Drivers and mechanisms for enhanced summer monsoon precipitation over East Asia during the mid-Pliocene in the IPSL-CM5A. Climate Dyn., 46, 1437-1457, https://doi.org/ 10.1007/s00382-015-2656-4.

Tian, D., Y. Guo, and W. Dong, 2015: Future changes and uncertainties in temperature and precipitation over China based on CMIP5 models. Adv. Atmos. Sci., 32, 487-496, https://doi.org/ 10.1007/s00376-014-4102-7.
Tian, Z. P., and D. B. Jiang, 2015: Mid-Holocene and last glacial maximum changes in monsoon area and precipitation over China (in Chinese). Chin. Sci. Bull., 60, 400-410, https://doi.org/ 10.1360/N972014-00718.

Walsh, P. D., and D. M. Lawler, 1981: Rainfall seasonality: Description, spatial patterns and changes through time. Weather, 36, 201-208, https://doi.org/10.1002/j.1477-8696.1981.tb05400.x.

Wang, B., 2006: The Asian Monsoon. Springer, 787 pp.

- , and Q. Ding, 2006: Changes in global monsoon precipitation over the past 56 years. Geophys. Res. Lett., 33, L06711, https:// doi.org/10.1029/2005GL025347.

— - J. Liu, H.-J. Kim, P. J. Webster, and S.-Y. Yim, 2012: Recent change of the global monsoon precipitation (1979-2008). Climate Dyn., 39, 1123-1135, https://doi.org/10.1007/s00382-011-1266-z.

, S. Y. Yim, J. Y. Lee, J. Liu, and K. J. Ha, 2014: Future change of Asian-Australian monsoon under RCP 4.5 anthropogenic warming scenario. Climate Dyn., 42, 83-100, https://doi.org/ 10.1007/s00382-013-1769-x.

Wang, W. M., and J. W. Shu, 2004: Late Cenozoic palynofloras from Qujing Basin, Yunnan, China (in Chinese). Acta Palaeontol. Sin., 43, 254-261.

_, J. R. Li, J. D. Wang, and Z. J. He, 2002: Palynofloras from Pliocene balouhe formation and Pleistocene in Zhangqiu County, Shandong Province. Acta Palaeonotol. Sin., 41, 7276.

Wu, F. L., X. Fang, Y. Ma, M. Herrmann, V. Mosbrugger, Z. An, and Y. Miao, 2007: Plio-Quaternary stepwise drying of Asia: Evidence from a 3-Ma pollen record from the Chinese Loess Plateau. Earth Planet. Sci. Lett., 257, 160-169, https://doi.org/ 10.1016/j.epsl.2007.02.029.

-, M. Herrmann, V. Mosbrugger, and Y. F. Miao, 2011: Extended drought in the interior of Central Asia since the Pliocene reconstructed from sporopollen records. Global Planet. Change, 76, 16-21, https://doi.org/10.1016/j.gloplacha.2010.11.007.

Wu, J., and X. Gao, 2013: A gridded daily observation dataset over China region and comparison with the other datasets. Chin. J. Geophys., 56, 1102-1111, https://doi.org/10.6038/cjg20130406.

Wu, N. Q., Y. P. Pei, H. Y. Lu, Z. T. Guo, F. J. Li, and T. S. Liu, 2006: Marked ecological shifts during 6.2-2.4 Ma revealed by a terrestrial molluscan record from the Chinese Red Clay Formation and implication for palaeoclimatic evolution. Palaeogeogr. Palaeoclimatol. Palaeoecol., 233, 287-299, https://doi.org/ 10.1016/j.palaeo.2005.10.006.

Wu, Y. S., 2001: Palynoflora at late Miocene-early Pliocene from leijiahe of lingtai, Gansu Province, China (in Chinese). Acta Bot. Sin., 43, 750-756.

Xie, S., B. Sun, J. Wu, Z. Lin, D. Yan, and L. Xiao, 2012: Palaeoclimatic estimates for the Late Pliocene based on leaf physiognomy from western Yunnan, China. Turk. J. Earth Sci., 21, 251-261.

Yan, Q., Z. Zhang, and Y. Gao, 2012a: An East Asian monsoon in the mid-Pliocene. Atmos. Oceanic Sci. Lett., 5, 449-454, https:// doi.org/10.1080/16742834.2012.11447034.

- — - H. Wang, Y. Gao, and W. Zheng, 2012b: Set-up and preliminary results of mid-Pliocene climate simulations with CAM3.1. Geosci. Model Dev., 5, 289-297, https://doi.org/ 10.5194/gmd-5-289-2012.

,,,--- and R. Zhang, 2014: Simulation of the Greenland ice sheet during the mid-Pliocene. Chin. Sci. Bull., 59, 201-211, https://doi.org/10.1007/s11434-013-0001-z.

,-- , and,- 2016 a: Investigating uncertainty in the simulation of the Antarctic ice sheet during the mid-Piacenzian. J. Geophys. Res., 121, 1559-1574, https://doi.org/10.1002/ 2015JD023900. 
, T. Wei, R. L. Korty, J. P. Kossin, Z. Zhang, and H. Wang, 2016b: Enhanced intensity of global tropical cyclones during the mid-Pliocene warm period. Proc. Natl. Acad. Sci. USA, 113, 12 963-12 967, https://doi.org/10.1073/pnas.1608950113.

Yang, S., Z. Ding, Y. Li, X. Wang, W. Jiang, and X. Huang, 2015: Warming-induced northwestward migration of the East Asian monsoon rain belt from the Last Glacial Maximum to the midHolocene. Proc. Natl. Acad. Sci. USA, 112, 13 178-13183, https://doi.org/10.1073/pnas.1504688112.

Yang, S., K.-M. Lau, and K.-M. Kim, 2002: Variations of the East Asian jet stream and Asian-Pacific-American winter climate anomalies. J. Climate, 15, 306-325, https://doi.org/10.1175/ 1520-0442(2002)015<0306:VOTEAJ > 2.0.CO;2.

Yao, Y.-F., A. A. Bruch, Y. M. Cheng, V. Mosbrugger, Y.-F. Wang, and C.-S. Li, 2012: Monsoon versus uplift in southwestern China-Late Pliocene climate in Yuanmou Basin, Yunnan. PLOS ONE, 7, e37760, https://doi.org/10.1371/ journal.pone.0037760.

Yu, E., H. Wang, and J. Sun, 2010: A quick report on a dynamical downscaling simulation over China using the nested model. Atmos. Ocean. Sci. Lett., 3, 325-329, https://doi.org/10.1080/ 16742834.2010.11446886.

— J. Sun, H. Chen, and W. Xiang, 2015: Evaluation of a highresolution historical simulation over China: Climatology and extremes. Climate Dyn., 45, 2013-2031, https://doi.org/10.1007/ s00382-014-2452-6.

Zhang, R., and Coauthors, 2013: East Asian monsoon climate simulated in the PlioMIP. Climate Past, 9, 2085-2099, https:// doi.org/10.5194/cp-9-2085-2013.

- D. Jiang, and Z. Zhang, 2015: Causes of mid-Pliocene strengthened summer and weakened winter monsoons over
East Asia. Adv. Atmos. Sci., 32, 1016-1026, https://doi.org/ 10.1007/s00376-014-4183-3.

Zhang, Y., and Coauthors, 2010: Depositional facies and paleoenviromental record of the Late Tertiary stratum of Lanzhou Area, Gansu (in Chinese). Acta Sedimentol. Sin., 28, 611-619.

Zhang, Y. G., M. Pagani, and Z. Liu, 2014: A 12-million-year temperature history of the tropical Pacific Ocean. Science, 344, 84-87, https://doi.org/10.1126/science.1246172.

Zhang, Z., and Q. Yan, 2012: Pre-industrial and mid-Pliocene simulations with NorESM-L: AGCM simulations. Geosci. Model Dev., 5, 1033-1043, https://doi.org/10.5194/gmd-5-1033-2012.

— , X. Li, Q. Yan, and R. Zhang, 2016: Impact of changes in seaways on Chinese climate during Pliocene (in Chinese). Quat. Sci., 36, 768-774, https://doi.org/10.11928/j.issn.10017410.2016.03.25

Zheng, H., C. M. Powell, D. K. Rea, J. Wang, and P. Wang, 2004: Late Miocene and mid-Pliocene enhancement of the East Asian monsoon as viewed from the land and sea. Global Planet. Change, 41, 147-155, https://doi.org/10.1016/j.gloplacha.2004.01.003.

Zhou, B., Q. H. Wen, Y. Xu, L. Song, and X. Zhang, 2014: Projected changes in temperature and precipitation extremes in China by the CMIP5 multimodel ensembles. J. Climate, 27, 6591-6611, https://doi.org/10.1175/JCLI-D-13-00761.1.

Zhou, T. J., and R. C. Yu, 2005: Atmospheric water vapor transport associated with typical anomalous summer rainfall patterns in China. J. Geophys. Res., 110, D08104, https://doi.org/10.1029/ 2004JD005413.

_ - and L. Zou, 2010: Understanding the predictability of East Asian summer monsoon from the reproduction of land-sea thermal contrast change in AMIP-type simulation. J. Climate, 23, 6009-6026, https://doi.org/10.1175/2010JCLI3546.1. 